\title{
7. A AUTONOMIA FINANCEIRA DO PODER JUDICIÁRIO NO BRASIL
}

A previsão constitucional de autonomia financeira para o Poder Judiciário no Brasil, como mencionado, consta no texto da Constituição de 1988 no art. 99. Também o art. 168 da CF traz importante disposição garantidora dessa autonomia, ao determinar que a entrega dos recursos correspondentes ao Poder Judiciário seja feita até o dia 20 de cada mês.

Nas Constituições anteriores não havia essa referência expressa à autonomia financeira do Poder Judiciário, mas tão somente à independência dos Poderes, bem como ao pagamento de precatórios.

No Estado brasileiro, organizado sob a forma federativa, o Poder Judiciário constitui-se de vários órgãos, discriminados no art. 92 da CF: o Supremo Tribunal Federal, o Superior Tribunal de Justiça, os Tribunais Regionais Federais e Juízes Federais (que compõem a Justiça Federal), os Tribunais e Juízes do Trabalho (que compõem a Justiça do Trabalho), os Tribunais, Juízes e Juntas Eleitorais (que compõem a Justiça Eleitoral), os Tribunais e Juízes Militares (que compõem a Justiça Militar) e, por fim, os Tribunais e Juízes dos Estados, Distrito Federal e Territórios.

O STF, o STJ, os Tribunais Regionais Federais e Juízes Federais e os Tribunais e Juízes do Trabalho integram a esfera federal do Poder Judiciário, funcionando com servidores federais e com recursos da união. Há ainda o Conselho Nacional de Justiça, previsto no art. 92, I-A, da CF, com redação dada pela EC 45/04.

A Justiça Eleitoral também integra a esfera federal do Poder Judiciário, utilizando-se de recursos orçamentários da união; no entanto, faz uso frequente de servidores estaduais para prestar seus serviços. É composta pelo Tribunal Superior Eleitoral, pelos Tribunais Regionais Eleitorais, pelos Juízes Eleitorais e pelas Juntas Eleitorais. Como já mencionado no item 3.3, seu órgão máximo é o TSE, composto por sete membros, sendo três Ministros que integram o STF, dois Juízes que integram o STJ 
e outros dois Juízes nomeados entre seis advogados indicados pelo STF. Há um TRE na capital de cada Estado, composto por sete Juízes, sendo dois nomeados entre os Desembargadores do Tribunal de Justiça, dois entre Juízes de Direito escolhidos pelo Tribunal de Justiça, um Juiz do TRF ou Juiz Federal escolhido pelo referido Tribunal e outros dois Juízes escolhidos entre advogados indicados pelo Tribunal de Justiça e nomeados pelo Presidente da República. Cumpre ressaltar que os Desembargadores e juízes que integram o TRE continuam pertencendo ao quadro do Tribunal de Justiça do Estado, e dele recebendo seus vencimentos ${ }^{251}$, o que também ocorre com os Juízes Eleitorais, fazendo com que parte das despesas da Justiça Eleitoral seja coberta com recursos do Poder Judiciário estadual, embora formalmente ela integre a esfera federal do Poder Judiciário.

A Justiça Militar apresenta situação peculiar. São órgãos da Justiça Militar o Superior Tribunal Militar e os Tribunais e Juízes Militares. O STM compõe-se de quinze Ministros, nomeados pelo Presidente da República, na forma do art. 123 da CF.

Nos Estados em que o efetivo da polícia militar supere 20 mil integrantes, pode ser criada a Justiça Militar Estadual, como em São Paulo, que prevê a existência do Tribunal de Justiça Militar do Estado, composto por sete juízes (art. 80 da CE).

Assim, a Justiça Militar tem natureza mista no aspecto federativo, sendo parte dela federal e parte estadual, situação refletida no aspecto orçamentário, como se verá posteriormente.

Os Estados organizam sua própria Justiça, observados os princípios estabelecidos na Constituição Federal (art. 125), cuja competência é residual, cabendolhes julgar as causas não afetas aos demais Tribunais, aos quais a Constituição Federal expressamente definiu atribuições. Lei estadual poderá criar a Justiça Militar estadual, com competência para processar e julgar os policiais militares e bombeiros militares nos crimes militares, nos termos do art. $125, \S 4^{\circ}$, da CF.

A organização do Poder Judiciário no aspecto orçamentário prevê, entre os mecanismos que podem assegurar a autonomia financeira, à qual se fez referência no

${ }^{251}$ Acrescidos de gratificação paga pela Justiça Eleitoral, com recursos federais. 
capítulo 6, a administração de fundos especiais. É o recurso que mais tem sido utilizado para essa finalidade.

A seguir, será feita uma análise do Poder Judiciário brasileiro, quanto à sua organização em matéria orçamentária, destacando-se os mecanismos utilizados para garantir sua autonomia financeira, especialmente a administração de fundos.

As referências à legislação estadual levarão em conta os dispositivos em vigor em dezembro de 2004, antes da publicação da EC 45. Isso se justifica porque, na referida emenda, entre as várias alterações promovidas, está a inclusão do $\S 2^{\circ}$ no art. 98, com a previsão de que "as custas e emolumentos serão destinados exclusivamente ao custeio dos serviços afetos às atividades específicas da Justiça". Com isso, tem havido alterações nas leis estaduais, pois nem todas asseguravam essa destinação integral dos recursos a que se fez menção. ${ }^{252}$

\subsection{Esfera federal}

Para fins orçamentários, o Poder Judiciário, na esfera federal, está organizado da forma descrita a seguir.

No orçamento da união para 2004, o Poder Judiciário divide-se em sete órgãos (e respectivo código), a saber: Supremo Tribunal Federal (10000), Superior Tribunal de Justiça (11000), Justiça Federal (12000), Justiça Militar da união (13000), Justiça Eleitoral (14000), Justiça do Trabalho (15000) e Justiça do Distrito Federal e dos Territórios (16000).

O STF, no orçamento de 2004, tinha apenas uma unidade orçamentária, também denominada Supremo Tribunal Federal (código 10101). O orçamento da união para $2006^{253}$ prevê duas unidades, acrescentando o Conselho Nacional de Justiça (Código 10102). O STJ tem apenas uma unidade, com a mesma denominação, que tem o código 11101.

\footnotetext{
${ }^{252}$ No Estado de São Paulo, o TJ editou a Resolução 196, de 19.1.2005, promovendo a alteração no montante dos recursos transferidos; no entanto, os efeitos desta Resolução foram suspensos por medida liminar concedida pelo STF na ADIn 3.401/SP.

${ }^{253}$ Lei 11.306, de 17.5.2006.
} 
A Justiça Federal tem seis unidades orçamentárias: a Justiça Federal de Primeiro Grau (12101), o Tribunal Regional Federal da $1^{\mathrm{a}}$ Região (12102), o Tribunal Regional Federal da $2^{\mathrm{a}}$ Região (12103), o Tribunal Regional Federal da $3^{\mathrm{a}}$ Região (12104), o Tribunal Regional Federal da $4^{\mathrm{a}}$ Região (12105) e o Tribunal Regional Federal da $5^{\mathrm{a}}$ Região (12106). A supervisão administrativa e financeira da Justiça Federal de primeiro e segundo graus é exercida pelo Conselho da Justiça Federal, órgão que funciona junto ao STJ (CF, art. 105, parágrafo único, II).

A Justiça Militar da união tem uma única unidade orçamentária, igualmente denominada Justiça Militar da União (13101).

A Justiça Eleitoral tem vinte e nove unidades orçamentárias: o Tribunal Superior Eleitoral (14101), vinte e sete Tribunais Regionais Eleitorais, sendo um para cada Estado da Federação ${ }^{254}$, e o Fundo Partidário (14901).

A Justiça do Trabalho é composta de vinte e cinco unidades orçamentárias: o Tribunal Superior do Trabalho (15101) e vinte e quatro Tribunais Regionais do Trabalho. ${ }^{255}$

Por fim, o Poder Judiciário Federal tem como órgão a Justiça do Distrito Federal e dos Territórios, com duas unidades orçamentárias: o Tribunal de Justiça do Distrito Federal (16101) e a Justiça da Infância e da Juventude (16103).

A autonomia financeira é assegurada pelos arts. 99 e 168 da CF, o que já foi demonstrado ao longo deste trabalho.

\subsection{Esfera estadual}

Os Estados, em face da autonomia administrativa e financeira, têm sua própria organização orçamentária do Poder Judiciário, observados os princípios estabelecidos pelos arts. 99 e 125 da CF.

Cabe à Constituição do Estado definir a competência dos Tribunais, sendo a lei de organização judiciária de iniciativa do Tribunal de Justiça (CF, art. 125, § $\left.1^{\circ}\right)$. Os

${ }^{254}$ Tribunal Regional Eleitoral do Acre (14.102), Tribunal Regional Eleitoral de Alagoas (14.103), etc. 
Estados poderão criar a Justiça Militar Estadual, como já dito. ${ }^{256}$ Alguns Estados, como São Paulo, tinham Tribunais de segunda instância de alçada inferior ao Tribunal de Justiça, chamados de Tribunais de Alçada, extintos com a EC 45/04.

\subsubsection{O Poder Judiciário no Estado de São Paulo}

No Estado de São Paulo, o Poder Judiciário é constituído pelo Tribunal de Justiça, Tribunal de Justiça Militar, Tribunais do Júri, Turmas de Recursos, Juízes de Direito, Auditorias Militares e Juizados Especiais (CE, art. 54). Os três Tribunais de Alçada existentes até dezembro de 2004 (Primeiro Tribunal de Alçada Civil, Segundo Tribunal de Alçada Civil e Tribunal de Alçada Criminal) foram extintos por força do art. $4^{\circ}$ da EC 45/04, publicada em 31.12.2004 e implementada pela Resolução do Órgão Especial 194, publicada em 4.1.2005.

No aspecto orçamentário, havia cinco unidades orçamentárias (e respectivo código): o Tribunal de Justiça (03001), o Primeiro Tribunal de Alçada Civil (04001), o Tribunal de Alçada Criminal (05001), o Tribunal de Justiça Militar (06001) e o Segundo Tribunal de Alçada Civil (22001). ${ }^{257}$ Com a extinção dos Tribunais de Alçada, passaram a ser duas as unidades orçamentárias: o Tribunal de Justiça (03001) e o Tribunal de Justiça Militar (06001). ${ }^{258}$

$\mathrm{O}$ art. 55 da $\mathrm{CE}$ lhe assegura expressamente a autonomia financeira, nos seguintes termos:

\footnotetext{
Art. 55. Ao Poder Judiciário é assegurada autonomia financeira e administrativa.

Parágrafo único. São assegurados, na forma do art. 99 da Constituição Federal, ao Poder Judiciário, recursos suficientes para manutenção, expansão e aperfeiçoamento de suas atividades jurisdicionais, visando ao acesso de todos à Justiça.
}

Na primeira fase de elaboração do orçamento, o Tribunal de Justiça deverá, dentro dos limites estipulados em conjunto com os demais poderes na lei de diretrizes

\footnotetext{
${ }^{255}$ TRT da $1^{\text {a }}$ Região - Rio de Janeiro (15.102), TRT da $2^{\text {a }}$ Região - São Paulo (15.103), etc.

${ }^{256}$ Quando o efetivo da Polícia Militar for superior a 20 mil integrantes. Ver CF, art. 125, $\S 3^{\circ}$.

${ }^{257}$ Orçamento para 2005 (Lei Estadual no 11.816 ), publicada em 31.12.2004.
} 
orçamentárias, por meio de seu Órgão Especial, elaborar a proposta orçamentária e a encaminhar ao Poder Executivo para inclusão no projeto de lei orçamentária.

É interessante notar que, antes da reforma constitucional promovida pela EC 45/2005, havia, no Poder Judiciário do Estado de São Paulo, uma autonomia financeira interna dos Tribunais de segundo grau, pois deveriam ser ouvidos por ocasião da elaboração da proposta orçamentária; além disso, o art. 78 da CE assegurava expressamente autonomia administrativa aos Tribunais de Alçada ${ }^{259}$. Cumpre ressaltar também que, como bem observa Samuel Alves de Melo Júnior ${ }^{260}$, o Regimento Interno do Tribunal de Justiça, em seu art. 217, XXXIV, atribuía competência ao Presidente do TJ para "autorizar despesas orçamentárias e determinar a instauração de licitação do Poder Judiciário do Estado, excluída a matéria de interesse dos Tribunais de Alçada”. Evidencia-se claramente, pois, que os extintos Tribunais de Alçada eram dotados de um razoável grau de autonomia financeira no Estado de São Paulo.

A administração de fundos especiais é mecanismo utilizado no Estado de São Paulo para que o Poder Judiciário exerça sua autonomia financeira.

O Fundo Especial de Despesa do Tribunal de Justiça (FED) está previsto na Lei Estadual $\mathrm{n}^{\mathrm{o}}$ 8.876/94, tendo sido criado com a finalidade de assegurar recursos para expansão e aperfeiçoamento da atividade jurisdicional, visando ampliar o acesso à Justiça, com destinação de seus recursos para as atividades de modernização administrativa do TJ, informatização e aperfeiçoamento de servidores e magistrados. As receitas do fundo, conforme prevê o art. $3^{\circ}$ do referido diploma legal, com a redação dada pelas Leis Estaduais $n^{0} 9.653 / 97$ e $n^{0} 11.608 / 03$, consistem basicamente em participação na arrecadação da taxa judiciária (21\% do montante), em recursos obtidos com extração de cópias reprográficas, em inscrições em concursos públicos, na venda de materiais, em doações e aplicações financeiras, na prestação de serviços de

\footnotetext{
${ }^{258}$ Orçamento para 2006 - Lei Estadual 12.298, de 8 de março de 2006.

${ }^{259} \mathrm{O}$ art. 56 da Constituição Estadual tinha a seguinte redação: "Ouvidos os demais Tribunais de segundo grau, dentro dos limites estipulados conjuntamente com os demais Poderes na lei de diretrizes orçamentárias, o Tribunal de Justiça, pelo seu Órgão Especial, elaborará proposta orçamentária do Poder Judiciário, encaminhando-a, por intermédio de seu Presidente, ao Poder Executivo, para inclusão no projeto de lei orçamentária". Com o advento da Emenda Constitucional Federal 45/2005, e o julgamento da ADIn 2.011-1, a redação passou a ser a que foi dada pela Emenda Constitucional Estadual 8/99, excluindo-se a expressão "ouvidos os demais Tribunais de segundo grau".

${ }^{260}$ Autonomia orçamentária..., p. 2.
} 
informações, nas multas contratuais e em outras receitas. Acrescente-se, ainda, a participação na arrecadação dos emolumentos relativos aos atos praticados pelos serviços notariais e de registro. ${ }^{261}$ Esse fundo é vinculado ao TJ, a quem compete administrá-lo e fixar suas diretrizes operacionais (Lei $n^{\circ} 8.876 / 94$, art. $1^{\circ}$ e $6^{\circ}$ ).

Para que se possa ter uma noção de valores financeiros, o Fundo Especial de Despesa do Tribunal de Justiça, no ano de 2003, arrecadou aproximadamente R\$ 135 milhões, sendo essa a maior arrecadação desde que foi criado. A despesa total do Tribunal de Justiça no período, pelo critério do crédito empenhado, corresponde a R\$ 2.660.295.549,00. ${ }^{262}$

A Lei $n^{0}$ 9.653/97 criou quatro outros fundos, vinculados aos demais Tribunais do Estado, a saber: a) o Fundo Especial de Despesa - Poder Judiciário - Primeiro Tribunal de Alçada Civil do Estado de São Paulo (art. 1º, I); b) o Fundo Especial de Despesa - Poder Judiciário - Segundo Tribunal de Alçada Civil do Estado de São Paulo (art. $\left.1^{\mathrm{o}}, \mathrm{II}\right)$; c) o Fundo Especial de Despesa - Poder Judiciário - Tribunal de Alçada Criminal do Estado de São Paulo (art. ${ }^{\circ}$, III); e d) o Fundo Especial de Despesa - Poder Judiciário - Tribunal de Justiça Militar do Estado de São Paulo (art. 1 ${ }^{\circ}$, IV). As finalidades desses fundos, bem como suas receitas, estão previstas nos arts. $2^{\circ}$ e $3^{\circ}$ do referido diploma legal e são basicamente as mesmas do Fundo Especial de Despesa do Tribunal de Justiça. No que tange às receitas, cabe-lhes o porcentual de $9 \%$ do montante arrecadado com a taxa judiciária, sendo 3\% para o Fundo de Despesa do Primeiro Tribunal de Alçada Civil, 3\% para o Fundo de Despesa do Segundo Tribunal de Alçada Civil e 3\% para o Fundo de Despesa do Tribunal de Alçada Criminal, não havendo participação nos emolumentos dos serviços notariais e de registro.

Não obstante a importância crescente dos fundos como instrumentos destinados a aumentar o grau de autonomia financeira do Poder Judiciário no Estado de São Paulo, vê-se que a participação deles ainda é pequena. No ano de 2003, 97\% das despesas totais do Tribunal de Justiça do Estado de São Paulo foram efetuadas com recursos do Tesouro do Estado. ${ }^{263}$

\footnotetext{
${ }^{261}$ Esta participação é de $3,289473 \%$ do valor arrecadado, conforme estabelece o art. $19, e$, da Lei ${ }^{\circ}$ 11.331/02. Texto da lei vigente em dezembro de 2004.

${ }^{262}$ TRIBUNAL DE JUSTIÇA DO ESTADO DE SÃO PAULO. Relatório anual de gestão 2003, p. 105 e 107.

${ }^{263}$ Idem, p. 108.
} 


\subsubsection{O Poder Judiciário no Estado do Rio de Janeiro}

O Poder Judiciário no Estado do Rio de Janeiro prevê, como órgão de segunda instância, o Tribunal de Justiça, uma vez que os Tribunais de Alçada foram extintos pela EC Estadual 7/98. Há Conselhos de Justiça Militar, com competência para julgar os integrantes da Polícia Militar e do Corpo de bombeiros Militar, funcionando o TJ como órgão de segundo grau.

A autonomia financeira é assegurada pelo art. 152 da CE, nos seguintes termos:

\footnotetext{
Art. 152. Ao Poder Judiciário é assegurada autonomia administrativa e financeira.

$\S 1^{\circ}-\mathrm{O}$ Tribunal de Justiça elaborará a proposta orçamentária do Poder Judiciário dentro dos limites estipulados em conjunto com os demais Poderes na Lei de Diretrizes Orçamentárias.

$\S 2^{\circ}-\mathrm{O}$ encaminhamento da proposta, depois de aprovada pelo Tribunal de Justiça, será feito pelo seu Presidente, à Assembleia Legislativa.
}

Deve ser ressaltada uma diferença de grande relevância entre os dispositivos das Constituições do Estado de São Paulo e do Rio de Janeiro.

No caso da Constituição fluminense, a proposta orçamentária do Poder Judiciário, uma vez elaborada, é encaminhada diretamente à Assembleia Legislativa, conforme prevê o $\S 2^{\circ}$ do art. 152, enquanto o art. 56 da Constituição paulista prevê o encaminhamento ao Poder Executivo para inclusão no projeto de lei orçamentária. A Constituição Federal não é absolutamente clara no tocante a esse ponto, mas se mostra evidentemente melhor a redação estabelecida pela Constituição do Estado do Rio de Janeiro, mais coerente com o princípio da separação de poderes e com a autonomia financeira do Poder Judiciário, pois não deixa margem a dúvidas quanto à impossibilidade do Poder Executivo alterar a proposta orçamentária encaminhada pelo Poder Judiciário. ${ }^{264}$

${ }^{264}$ Conforme já se discutiu no item 4.4.4. 
A autonomia financeira do Poder Judiciário do Estado do Rio de Janeiro tem sido objeto de referência na imprensa, com elogios aos resultados alcançados em decorrência de sua implementação. ${ }^{265}$

O principal mecanismo que permitiu essa autonomia financeira é a administração de um fundo especial, com a diferença, em relação aos demais Estados, que a quantidade de recursos que o compõem é maior, permitindo fazer frente às despesas gerais do Poder Judiciário, excluídas as despesas com pessoal, que continuam a ser pagas pelo Tesouro do Estado. ${ }^{266}$ Ângela Carvalho observa que, com o advento do Fundo Especial do Tribunal de Justiça (FETJ), praticamente todas as despesas de capital e investimento passaram a ser pagas com recursos desse fundo. ${ }^{267}$

O FETJ foi criado pela Lei Estadual $n^{\circ} 2.254 / 96$, tendo por objetivo dotar o Poder Judiciário de recursos financeiros para sua modernização e reaparelhamento, mediante elaboração e execução de projetos, ampliação e reformas de suas dependências, informatização e aquisição de material permanente $\left(\operatorname{art.} 1^{\circ}\right)$. Suas receitas provêm, conforme previsto na lei que o criou, de diversas fontes, destacando-se as dotações orçamentárias, custas e emolumentos judiciais, prestações de serviços a terceiros, inscrições em concursos, cursos e congressos, venda de publicações, aluguéis e permissões de uso, alienações de bens e aplicações financeiras. Deu-se um grande incremento às receitas do fundo com a Lei $n^{\circ} 3.217 / 99$, que transferiu ao FETJ o porcentual de $20 \%$ das custas remuneratórias dos atos de valor declarado praticados pelas serventias do foro extrajudicial, que passaram, juntamente com as custas e a taxa judiciária, a ser recolhidas em favor do fundo.

A lei de diretrizes orçamentárias estadual para 2004 (Lei Estadual n ${ }^{\circ} 4.130 / 03$ ) prevê, em seu art. $6^{\circ}$, que as propostas orçamentárias dos Poderes Judiciário e Legislativo, do Tribunal de Contas do Estado, do Ministério Público, da ProcuradoriaGeral do Estado e da Defensoria Pública Geral do Estado deverão ser elaboradas na forma e conteúdo nela estabelecidos. No entanto, não consta do texto da lei referência à

\footnotetext{
${ }^{265}$ A população agradece. Governo do Rio dá autonomia financeira e revoluciona o atendimento do Judiciário. Revista Isto É, n. 1779, 5.11.2003, p. 30; O exemplo que vem do Rio. Revista Exame, ed. 380, ano 38 , n. $22,10.11 .2004$, p. $40-1$.

${ }^{266}$ SALOMÃO, Luís Felipe. Magistratura sua participação..., p. 47, nota de rodapé 12.

${ }^{267}$ Autonomia financeira..., p. 234.
} 
fixação dos limites das despesas dos referidos poderes e instituições, como determina o art. $99, \S 1^{\circ}$, da CF e art. $152, \S 1^{\circ}$, da CE.

No que se refere às funções essenciais à Justiça, é interessante notar que a Constituição do Estado do Rio de Janeiro expressamente assegura autonomia financeira ao Ministério Público (art. 170, $\S 2^{\circ}$ ), à Procuradoria-Geral do Estado (art. 176, $\S 5^{\circ}$ ) e à Defensoria Pública (art. 181, I, b), em texto anterior à publicação da EC 45/04.

\subsubsection{O Poder Judiciário no Estado de Santa Catarina}

O Poder Judiciário no Estado de Santa Catarina tem o Tribunal de Justiça como órgão de segunda instância. A Justiça Militar conta com os Conselhos de Justiça, que funcionam como órgãos de primeiro grau, cuja competência é processar e julgar os integrantes da Polícia Militar nos crimes militares (CE, art. 90), funcionando o TJ como órgão de segundo grau.

A autonomia financeira é assegurada pelo art. 81 da CE, cuja redação é semelhante à do art. $99 \mathrm{da} \mathrm{CF}$.

A lei de diretrizes orçamentárias estadual para 2005 (Lei Estadual n ${ }^{\circ}$ 13.095/04), em seu art. 25, prevê limites para as despesas com a Assembleia Legislativa, Tribunal de Contas, Tribunal de Justiça, Ministério Público e para a universidade do Estado de Santa Catarina, fixando-os em porcentuais da Receita Líquida Disponível (RLD). Para o Tribunal de Justiça do Estado, é previsto o porcentual de 7\%.

No entanto, embora o artigo refira-se a limites, o que faz presumir serem os porcentuais previstos destinados a estabelecer o valor máximo de despesas, na verdade tais porcentuais funcionam como os valores transferidos aos órgãos mencionados.

A própria redação do art. 25 , em outro trecho, dá margem a essa interpretação. Diz o $\S 3^{\circ}$, fazendo referência ao porcentual da Assembleia Legislativa, que "ficam assegurados, para o exercício de 2005, além do percentual estabelecido no inciso I deste artigo, os recursos necessários à ampliação e reforma do Palácio Barriga-Verde”. 
No mesmo sentido consta informação no site do TJ de Santa Catarina, ao afirmar:

\begin{abstract}
A Lei 12.381 , de 23 de julho de 2002, que dispõe sobre as diretrizes orçamentárias para o exercício financeiro de 2003, em seu art. 23, inciso III, estabelece que o orçamento do Tribunal de Justiça do Estado será composto de 6,5\% da Receita Líquida Disponível do Estado - RLD. ${ }^{268}$
\end{abstract}

Assim, vê-se que o Estado de Santa Catarina acaba adotando um mecanismo de participação na receita orçamentária, assegurando ao Tribunal de Justiça um porcentual fixo, calculado com base na Receita Líquida Disponível, para garantir a autonomia financeira do Poder Judiciário. Há de se observar uma fragilidade no mecanismo adotado pelo Estado de Santa Catarina, pois o porcentual é fixado na lei de diretrizes orçamentárias, que pode ser alterada todos os anos. E também é frágil a interpretação que se tem dado aos artigos da LDO catarinense ao fixar esse porcentual, pois estabelecem limites, que devem ser interpretados como valores máximos, e não como valores fixos, como vem ocorrendo.

O Estado de Santa Catarina prevê um fundo, o Fundo de Reaparelhamento da Justiça (FRJ), criado pela Lei Estadual $n^{\mathrm{o}} 8.067 / 90 .{ }^{269}$ O FRJ tem por finalidade "o fortalecimento de recursos financeiros, destinados ao reequipamento físico e tecnológico do Poder Judiciário, Ministério Público, das unidades prisionais e dos estabelecimentos destinados a atendimento da política de proteção aos direitos da Criança e do Adolescente" (art. $2^{\circ}$, com redação alterada pela LC 188/99).

Suas receitas constituem-se basicamente em dotações orçamentárias, em receitas dos cartórios judiciais oficializados, nas custas dos cartórios judiciais e extrajudiciais ${ }^{270}$, na taxa judiciária, nas doações, nas transferências e auxílios, em alienação de bens, em aplicações financeiras, na venda de selos de fiscalização, além de outras fontes. É administrado por uma comissão nomeada pelo Presidente do TJ, com participação de um representante da $\mathrm{OAB}$.

\footnotetext{
${ }^{268}$ Disponível em: www.tj.sc.gov.br/adm/financas/financas.htm. Acesso em: 12 nov. 2004.

${ }^{269} \mathrm{O}$ fundo chamava-se inicialmente Fundo de Reaparelhamento do Poder Judiciário, mas teve sua denominação alterada pela Lei ${ }^{\circ} 8.362 / 91$.

${ }^{270}$ Receitas de custas que excederem o limite máximo fixado, no Regimento de Custas, para os Serventu-
} 


\subsubsection{O Poder Judiciário no Estado do Paraná}

No Paraná, o Poder Judiciário tem como órgão de segunda instância o Tribunal de Justiça. ${ }^{271} \mathrm{Na}$ primeira instância, há os Tribunais do Júri, Juízes de Direto e Substitutos, Juizados Especiais e Juízes de Paz. A Justiça Militar tem como órgãos de primeira instância os Conselhos de Justiça, competindo-lhes julgar os policiais militares nos crimes militares (CE, art. 93).

O orçamento de 2004 (Lei Estadual $\mathrm{n}^{\mathrm{o}}$ 14.275/03) previa três unidades orçamentárias (e respectivos códigos): o Tribunal de Justiça (0501), o Tribunal de Alçada (0701) e o Fundo de Reequipamento do Poder Judiciário - FUNREJUS (0560). No orçamento de 2006, já adaptado aos efeitos da reforma promovida pela EC Federal 45/2005, são apenas duas as unidades orçamentárias, ficando excluído o Tribunal de Alçada (Lei Estadual nº 14.977/05).

A autonomia financeira é assegurada pelo art. 98 da CE, cuja redação é semelhante à do art. 99 da CF.

O FUNREJUS é importante mecanismo do Poder Judiciário paranaense, assegurando-lhe recursos e aumentando seu grau de autonomia financeira. Está previsto na Lei Estadual $n^{0} 12.216 / 98$, com as alterações da Lei Estadual $n^{0} 12.604 / 99$. Tem por função dotar o Poder Judiciário de recursos para despesas com aquisição, construção, ampliação e reforma de edificações, aquisição de equipamentos, implementação de serviços de informática e outras despesas de custeio, excetuando-se gastos com pessoal. As receitas do fundo são constituídas por dotações orçamentárias, receitas de cópias reprográficas, participação em atos praticados por cartórios de protesto, $50 \%$ de custas decorrentes de atos dos Tribunais de Justiça e de Alçada, inscrições em concursos, alienação de bens, parte do produto da arrecadação da taxa judiciária, aplicações financeiras, multas contratuais, permissões de uso, além de outras fontes. A taxa judiciária é arrecadada pelo FUNREJUS, que fica com 50\% do valor apurado, devendo

ários e Auxiliares da Justiça, dos cartórios judiciais e extrajudiciais, na forma do art. $9^{\circ}$ da Lei (Lei ${ }^{\circ}$ $8.067 / 99$, art. $3^{\circ}$, III).

${ }^{271}$ Havia o Tribunal de Alçada, extinto por força da EC 45/04. 
destinar $48 \%$ para o Fundo Penitenciário e $2 \%$ para o fomento à pesquisa científica e tecnológica.

No Paraná, o sistema de elaboração orçamentária prevê a fixação de um porcentual da Receita Geral do Tesouro Estadual para o Poder Judiciário na lei de diretrizes orçamentárias, à semelhança do que ocorre no Estado de Santa Catarina.

A Lei Estadual $n^{\circ} 14.468 / 04$ (LDO para 2005) prevê, em seu art. $6^{\circ}$, o limite porcentual de $8,5 \%$ para o Poder Judiciário ${ }^{272}$, que deverá elaborar sua proposta orçamentária seguindo esse parâmetro.

A LDO do Paraná para o exercício de 2005 determina que as propostas orçamentárias dos Poderes Legislativo e Judiciário sejam apresentadas ao Poder Executivo para consolidação no Orçamento Geral do Estado.

O Paraná chegou a tentar fixar um limite máximo para as despesas do Poder Judiciário na Constituição Estadual, incluindo, no $\S 1^{\circ}$ do art. 98 , a redação: "sendo que o montante de recursos a ele destinado não poderá ser superior a seis por cento da receita geral do Estado, excluídos os precatórios, as operações de crédito e participações nas transferências da União".

No entanto, tal dispositivo foi impugnado por meio de Ação Direta de Inconstitucionalidade movida pelo Procurador-Geral da República. O STF, em medida cautelar, suspendeu sua eficácia (ADIn 468-9/PR, rel. Min. Celso de Mello, em 27.2.1992).

\subsubsection{O Poder Judiciário no Estado do Rio Grande do Sul}

O Poder Judiciário no Estado do Rio Grande do Sul prevê, como órgão de segunda instância, o Tribunal de Justiça, uma vez que o Tribunal de Alçada foi extinto pela EC Estadual 22/97. Há o Tribunal Militar do Estado, como órgão de segunda

\footnotetext{
272 “Art. $6^{\circ}$. A elaboração das propostas dos Poderes Legislativo e Judiciário e do Ministério Público será feita dentro dos seguintes limites percentuais da Receita Geral do Tesouro Estadual disponível para a fixação da despesa, depois de excluídas as parcelas de transferências constitucionais aos Municípios, as operações de crédito, as participações nas transferências da união e as receitas vinculadas: Poder Legislativo - 5,0\%; Poder Judiciário - 8,5\%; Ministério Público - 3,6\%. Parágrafo único - Do percentual destinado ao Poder Legislativo, caberá ao Tribunal de Contas o percentual de 1,90\%."
} 
instância da Justiça Militar, funcionando os Conselhos da Justiça Militar como órgãos de primeira instância (CE, arts. 91 e 104).

Não há referência expressa à autonomia financeira na Constituição Estadual, como consta do art. 99 da CF; no entanto, o art. 95, ao enumerar as atribuições do Tribunal de Justiça, prevê, em seu inciso VII, que lhe compete "elaborar e encaminhar, depois de ouvir o Tribunal Militar do Estado, as propostas orçamentárias do Poder Judiciário, dentro dos limites estipulados conjuntamente com os demais Poderes, na lei de diretrizes orçamentárias”.

Na lei de diretrizes orçamentárias para 2004 (Lei Estadual $n^{0} 11.946 / 03$ ) está previsto que o Poder Judiciário encaminhará sua proposta orçamentária ao órgão central de orçamento, por meio do Sistema de Elaboração da Proposta Orçamentária (EPO), para consolidação com as propostas das demais entidades da Administração estadual.

Os limites para as despesas do Poder Judiciário gaúcho estão fixados, para o exercício de 2004, na forma prevista no art. $4^{\circ}$ da LDO estadual, que utiliza sistema semelhante ao da LDO federal. Diz o art. $4^{\circ}$ que:

\footnotetext{
Os Poderes Legislativo e Judiciário e o Ministério Público terão como limites mínimos da previsão das dotações dos grupos "Outras Despesas Correntes" e "Despesas de Capital", para fins de elaboração de suas respectivas propostas orçamentárias de 2004, o conjunto de dotações fixadas para tais grupos na Lei Orçamentária de 2003, com as alterações decorrentes dos créditos suplementares e especiais, aprovados até 15 de maio de 2003, e como limite máximo de crescimento o percentual da Receita Tributária prevista para 2004 em relação à estimada no orçamento de 2003, excetuados os efeitos decorrentes da reclassificação entre grupos de despesas.
}

Essa forma de estabelecer limites evidencia o método de cálculo do tipo incrementativo que tem sido utilizado na elaboração dos orçamentos no Brasil, em que, a cada ano, são realizados aproximadamente os mesmos gastos dos anos anteriores, acrescentando-se eventuais despesas.

\subsubsection{O Poder Judiciário no Estado do Ceará}

O Poder Judiciário no Ceará tem como órgão de segunda instância o Tribunal de Justiça, previsto no art. 94, I, da CE. Há a previsão de Tribunais de Alçada no art. 94, 
III, objeto de ação no STF por meio da ADIn 251-1, que suspendeu os efeitos do dispositivo por decisão liminar. A discussão perdeu seu objeto a partir da publicação da EC 45/04.

A Constituição do Ceará prevê, ainda, um Conselho de Justiça Estadual (art. 94, II, e 106), “órgão de supervisão administrativa, orçamentária e de acompanhamento da regularidade do funcionamento dos órgãos de Justiça e do exercício funcional dos magistrados", que também está sub judice em razão das ADIn 136-1 e 251-1, tendo sido concedida liminar nesta última para suspender a eficácia do dispositivo. Cumpre destacar, nesta questão, a Súmula 649 do STF: "É inconstitucional a criação, por Constituição estadual, de órgão de controle administrativo do Poder Judiciário do qual participem representantes de outros Poderes ou entidades".

A Justiça Militar, competente para julgar os integrantes da Polícia Militar e do Corpo de bombeiros nos crimes militares, tem como órgãos de primeiro grau a Auditoria e o Conselho da Justiça Militar, submetendo-se as causas em segunda instância ao Tribunal de Justiça.

$\mathrm{O}$ art. 99 da $\mathrm{CE}$ assegura autonomia financeira ao Poder Judiciário, em dispositivo cuja redação assemelha-se ao artigo de mesmo número da $\mathrm{CF}$, com a diferença de que prevê o encaminhamento da proposta orçamentária do Tribunal de Justiça diretamente à Assembleia Legislativa $\left(\S 1^{\circ}\right)$.

Os limites para as despesas dos poderes estão fixados no art. 14 da lei de diretrizes orçamentárias para o exercício de 2005 (Lei Estadual n ${ }^{\circ}$ 13.514/04), de modo semelhante ao utilizado pela LDO da união para 2005:

Art. 14. Os Poderes Executivo, Legislativo, Judiciário e o Ministério Público Estadual terão, como limites das despesas correntes destinadas ao custeio de funcionamento e de manutenção, o conjunto das dotações fixadas na Lei Orçamentária de 2004, acrescidos dos valores dos créditos adicionais referentes às despesas da mesma espécie e de caráter continuado enviados à SEPLAN até 30 de junho de 2004, corrigidas para preços constantes de 2005 com base nos parâmetros macroeconômicos projetados para 2005, conforme o anexo de Metas Fiscais desta Lei.

Parágrafo único. Aos limites estabelecidos no caput deste artigo serão acrescidas as seguintes despesas: 
I - da mesma espécie das mencionadas no caput deste artigo e pertinentes ao exercício de 2005;

II - de manutenção e funcionamento de novas instalações em imóveis cuja aquisição ou conclusão esteja prevista para os exercícios de 2004 e 2005.

A LDO para 2005 determina que as propostas orçamentárias do Poder Judiciário e dos demais Poderes sejam encaminhadas ao Poder Executivo (Secretaria de Planejamento e Coordenação), para que este promova a consolidação do projeto de lei orçamentária $\left(\operatorname{art} .7^{\circ}\right)$.

O Poder Judiciário no Ceará administra um fundo, denominado FERMOJU (Fundo de Reaparelhamento e Modernização do Poder Judiciário), instituído pela Lei Estadual $n^{0}$ 11.891/91 (com alterações promovidas pela Lei Estadual 13.452/04), que tem por finalidade arrecadar recursos para projetos de descentralização e modernização, suprimento de materiais, modernização tecnológica e de informática, melhoria das instalações, etc. Suas receitas constituem-se basicamente do montante integral da taxa judiciária, 5\% das custas judiciais, 5\% dos emolumentos de protestos, escrituras e registros públicos, inscrições em cursos, seminários e concursos públicos, aplicações financeiras, dotações orçamentárias, multas aplicadas em processos cíveis e criminais, além de outras fontes.

\subsubsection{O Poder Judiciário no Estado de Minas Gerais}

O Poder Judiciário em Minas Gerais tem como órgãos de segunda instância o Tribunal de Justiça e o Tribunal de Justiça Militar. ${ }^{273}$

Em matéria orçamentária, eram três as unidades orçamentárias em 2005 (e respectivos códigos): o Tribunal de Justiça (1.03.0), o Tribunal de Alçada (1.04.0) e o Tribunal de Justiça Militar (1.05.0). O orçamento de 2006 (Lei Estadual 15.970/06) já exclui a unidade orçamentária Tribunal de Alçada, extinto por força da EC 45/2005.

O art. 97 da CE prevê a autonomia financeira do Poder Judiciário, trazendo em seu $\S 1^{\circ}$ referência a importante mecanismo destinado a assegurá-la: "Quando o regular exercício das funções do Poder Judiciário for impedido pela não satisfação oportuna das

${ }^{273}$ A EC 45/04 determinou a extinção do Tribunal de Alçada. 
dotações que lhe correspondam, caberá ao Tribunal de Justiça, pela maioria de seus membros, solicitar ao Supremo Tribunal Federal intervenção da união no Estado".

A intervenção federal, na hipótese mencionada, está prevista no art. 34, IV, combinado com o art. 36, I, da CF, que prevê a possibilidade de intervenção da união nos Estados para garantir o livre exercício dos poderes. ${ }^{274}$

Segundo os referidos dispositivos constitucionais, "a união não intervirá nos Estados nem no Distrito Federal, exceto para garantir o livre exercício de qualquer dos Poderes nas unidades da Federação" (CF, art. 34, IV), intervenção essa cuja decretação dependerá "de requisição do Supremo Tribunal Federal, se a coação for exercida contra o Poder Judiciário" (CF, art. 36, I).

Embora tal instrumento não dependa de menção expressa na Constituição Estadual para ser utilizado, a referência da Constituição mineira é de grande importância, pois cita expressamente a situação de frustração na entrega de recursos, extirpando qualquer dúvida de que configura hipótese que enseja a requisição de intervenção. Está, portanto, em perfeita sintonia com a necessidade de instrumentos que assegurem a autonomia financeira do Poder Judiciário.

A intervenção federal voltará a ser abordada com maior profundidade no item 7.4, por ser importante mecanismo destinado a assegurar o pagamento dos precatórios judiciários.

Outra inovação mineira é a criação de comissão permanente destinada a compatibilizar as propostas dos três Poderes e do Ministério Público por ocasião da elaboração da lei de diretrizes orçamentárias (CE, art. 155, § $\left.2^{\circ}\right)$.

A Comissão de Compatibilização e Acompanhamento Orçamentário, prevista na Lei Estadual $n^{\circ} 10.572 / 91$, é composta por cinco membros, sendo um indicado pela Mesa da Assembleia, um pelo Governador do Estado, um pelo Presidente do Tribunal

274 “Art. 34. A União não intervirá nos Estados nem no Distrito Federal, exceto para: [...] IV - garantir o livre exercício de qualquer dos Poderes nas unidades da Federação." "Art. 36. A decretação da intervenção dependerá: I - no caso do art. 34, IV, de solicitação do Poder Legislativo ou do Poder Executivo coacto ou impedido, ou de requisição do Supremo Tribunal Federal, se a coação for exercida contra o Poder Judiciário." 
de Justiça, um pelo Procurador-Geral de Justiça e um pelo Presidente do Tribunal de Contas $\left(\operatorname{art} .2^{\circ}\right)$. Compete a essa Comissão receber as propostas parciais dos três Poderes, do Ministério Público e do Tribunal de Contas para a elaboração do projeto de lei orçamentária, emitindo laudo conclusivo sobre a capacidade financeira do Estado de arcar com as despesas previstas. A Comissão deve indicar os limites de despesa dos órgãos envolvidos e proceder, em regime de colaboração, à compatibilização das propostas parciais, fornecendo os elementos para a elaboração da proposta definitiva $\left(\right.$ art. $3^{\circ}$ ). Esses limites devem ter como parâmetro o montante global da lei orçamentária anterior (LDO para 2005, art. 17, I); devem, ainda, acompanhar a elaboração do orçamento anual e verificar os limites previstos na LDO, além de outras atribuições.

A LDO para 2005 (Lei Estadual $n^{\circ}$ 15.291/04) estabelece que a proposta orçamentária do Poder Judiciário será encaminhada ao Poder Executivo (Secretaria de Estado de Planejamento e Gestão), por meio do sistema informatizado SIAFI-MG, ao qual competirá consolidar o projeto de lei orçamentária (art. $7^{\circ}$ ).

$\mathrm{Na}$ Constituição de Minas Gerais existe também um dispositivo peculiar em matéria de autonomia financeira, relacionado ao Poder Legislativo, cuja referência é interessante mencionar, por ser mecanismo útil para elevar o grau da referida autonomia.

$\mathrm{O}$ art. $62, \mathrm{~V}$, da Constituição mineira, prevê, como competência privativa da Assembleia Legislativa, "aprovar crédito suplementar ao orçamento de sua Secretaria", poder que se consolida na lei orçamentária (Orçamento para 2004 - Lei $n^{\circ}$ 15.031/04) ao estabelecer, em seu art. $9^{\circ}$, que "fica a Assembleia Legislativa autorizada a abrir créditos suplementares ao seu orçamento até o limite de 7\% (sete por cento) da despesa nele fixada, em conformidade com o disposto no art. 62, V, da Constituição". Esses créditos suplementares "utilizarão como fonte de recursos os resultantes da anulação parcial ou total de dotações orçamentárias do próprio orçamento suplementado e serão abertos por regulamento próprio da Assembleia Legislativa”. Este ato é acompanhado pela Comissão de Compatibilização e Acompanhamento Orçamentário (Lei $\mathrm{n}^{\mathrm{o}}$ $10.572 / 91$, art. $\left.3^{\circ}, \mathrm{VI}\right)$. 
Assim, vê-se que a Assembleia Legislativa tem autonomia para aprovar créditos suplementares de seu interesse, sem necessidade de alteração legislativa, nem de pleiteá-los junto ao Poder Executivo, que poderia concedê-los usando eventual margem de remanejamento.

\subsubsection{O Poder Judiciário no Estado do Espírito Santo}

O Tribunal de Justiça é o órgão de cúpula do Poder Judiciário capixaba, competindo-lhe, entre outras atribuições, decidir em segunda instância os processos da Justiça Estadual.

A autonomia financeira é assegurada pelo art. 105 da CE, cuja redação é semelhante à do art. 99 da CF.

Em matéria de orçamentos, o Poder Judiciário tem duas unidades orçamentárias: o Tribunal de Justiça do Estado do Espírito Santo (TJES) e a Corregedoria Geral da Justiça (CGJ).

A proposta orçamentária do Poder Judiciário é encaminhada ao Poder Executivo, nos termos do art. 13 da LDO para 2005 (Lei Estadual no 7.840/04). Referida lei prevê, ainda, que eventuais alterações na modalidade de aplicação dos recursos, aprovados na lei orçamentária e nos créditos adicionais, poderão se dar por "ato administrativo próprio dos responsáveis por cada órgão integrante dos Poderes Executivo, Legislativo e Judiciário e do Ministério Público” (art. 14, § $4^{\circ}$ ).

O Poder Judiciário do Estado do Espírito Santo administra um fundo, o Fundo Especial do Poder Judiciário do Estado do Espírito Santo - FUNEPJ, criado pela LC Estadual 219/01. Esse fundo tem por objetivo "a dotação de recursos financeiros ao processo de modernização e reaparelhamento do Poder Judiciário", por meio de elaboração e execução de programas e projetos, construção, ampliação, reforma e conservação de edificações, ampliação e modernização de serviços informatizados. Suas receitas compõem-se basicamente de dotações orçamentárias, taxas judiciárias, custas judiciais e emolumentos, prestações de serviços, inscrições em concursos públicos, 
cursos e congressos, venda de publicações, aluguéis e permissões de uso, alienações de bens, aplicações financeiras, penalidades pecuniárias, além de outras fontes.

\subsection{Questões sobre a autonomia financeira interna do Poder Judiciário no Brasil}

O Poder Judiciário brasileiro é, como se pode ver, uma organização de grandes dimensões, comportando uma série de divisões internas. Viu-se que, em decorrência da adoção do regime federativo, temos o Poder Judiciário Federal e os Poderes Judiciários Estaduais e Distrital. Cada um deles, por sua vez, comporta outras formas de divisões, dando origem a uma série de órgãos que se relacionam entre si e juntos compõem o Poder Judiciário do Brasil.

Essas divisões geram algumas questões que merecem ser refletidas, relacionadas à autonomia financeira, em especial quanto ao modo como ela funciona internamente.

Relativamente ao exercício da autonomia financeira, no que tange ao aspecto da elaboração da proposta orçamentária, cumpre destacar que a Constituição Federal, no seu art. 99, assegura autonomia financeira ao Poder Judiciário, em redação reproduzida de maneira semelhante na maior parte das Constituições Estaduais. Em seguida, o $\S 1^{\circ}$ estabelece que: "os tribunais elaborarão suas propostas orçamentárias dentro dos limites estipulados conjuntamente com os demais Poderes na lei de diretrizes orçamentárias" (grifo nosso). $\mathrm{O} \S 2^{\circ}$ assevera que "o encaminhamento da proposta, ouvidos os outros tribunais interessados, compete: I - no âmbito da união, aos Presidentes do Supremo Tribunal Federal e dos Tribunais Superiores, com a aprovação dos respectivos tribunais; II - no âmbito dos Estados e no do Distrito Federal e Territórios, aos Presidentes dos Tribunais de Justiça, com a aprovação dos respectivos tribunais" (grifo nosso).

Constata-se que não só no Poder Judiciário Federal, mas também no Poder Judiciário de vários Estados da Federação, há mais de um Tribunal compondo o Poder Judiciário. 
As leis de diretrizes orçamentárias que têm sido elaboradas, quando cumprem o disposto no art. 99, $\S 1^{\circ}$, fazem-no sem especificar o valor para cada um dos Tribunais que compõem o Poder Judiciário, fixando o limite globalmente.

O exercício da autonomia financeira envolve, pois, a elaboração de proposta orçamentária e a execução do orçamento de um Poder Judiciário que não tem necessariamente uma unidade interna, podendo existir conflito de interesses dentro dele. E o preceito constitucional, ao fazer referência à autonomia financeira, como se vê dos trechos reproduzidos, exige que sejam ouvidos os tribunais interessados.

Samuel Alves de Melo Júnior faz referência a essa questão, em artigo que discorre sobre a autonomia financeira dos Tribunais de Alçada de São Paulo. ${ }^{275}$ Mostra que, em face do que constava nos arts. $56^{276}$ e $78^{277}$ da Constituição Estadual (na redação vigente antes da promulgação da EC 45/05), as propostas orçamentárias dos Tribunais de Alçada somente poderiam ser elaboradas por eles. Fundamenta juridicamente sua posição nas leis e nos regulamentos estaduais que regiam a matéria, destacando o disposto no Regimento Interno do Tribunal de Justiça, que, em seu art. 217, XXXIV, prevê poderes ao Presidente da referida Corte para "autorizar despesas orçamentárias e determinar a instauração de licitação do Poder Judiciário do Estado, excluída a matéria de interesse dos Tribunais de Alçada".

A Constituição Federal, ao assegurar autonomia financeira ao Poder Judiciário, garante que todas as características a ela inerentes estarão presentes; e, como a própria redação menciona, ao Poder Judiciário. ${ }^{278}$ Ou seja, o Poder Judiciário, analisado como entidade única, tem autonomia financeira e pode exercê-la. A forma pela qual se dará o exercício dessa autonomia internamente é questão a ser resolvida dentro do Poder, que,

\footnotetext{
275 Autonomia..., p. 2.

276 “Art. 56. Ouvidos os demais Tribunais de segundo grau, dentro dos limites estipulados conjuntamente com os demais poderes na lei de diretrizes orçamentárias, o Tribunal de Justiça, pelo seu Órgão Especial, elaborará proposta orçamentária do Poder Judiciário, encaminhando-a, por intermédio de seu Presidente, ao Poder Executivo, para inclusão no projeto de lei orçamentária." (Redação vigente antes da EC Estadual 8/99 e da EC Federal 45/05).

277 “Art. 78. Os Tribunais de Alçada, dotados de autonomia administrativa, terão jurisdição, sede e número de juízes que a lei determinar e, desde que esse número seja superior a vinte e cinco, poderão criar órgão para o exercício das atribuições administrativas e jurisdicionais do Tribunal Pleno, e inclusive para uniformizar a jurisprudência divergente de suas Câmaras." (Redação vigente antes da EC Estadual 8/99 e da EC Federal 45/05)

278 "Art. 99. Ao Poder Judiciário é assegurada autonomia administrativa e financeira."
} 
como também prevê o art. 99 da CF, tem autonomia administrativa. Portanto, cabe ao Poder Judiciário, exercendo sua autonomia administrativa, decidir o mecanismo por meio do qual serão exercidas as autonomias financeiras de seus Tribunais, até porque, qualquer que seja a forma adotada, há de se cumprir integralmente o art. 99 da CF e seus dois primeiros parágrafos, que determinam a oitiva dos Tribunais por ocasião da elaboração da proposta orçamentária.

O mesmo raciocínio vale para a fase de execução do orçamento, em que medidas de contingenciamento, transposição, remanejamento e transferências poderão afetar o Poder Judiciário. Observadas as demais disposições constitucionais e legais, caberá a ele decidir, no âmbito interno, a alocação dos recursos da forma que melhor convier ao interesse público.

Ainda com relação à autonomia financeira interna, é interessante ressaltar as ponderações de Jatir Batista da Cunha, quando discorre sobre as transferências de recursos orçamentários entre Tribunais de Trabalho. Relata a ocorrência de transferências de recursos do TRT/MG para o TRT/SP, ocorridas nos anos de 1995 e 1996, cuja legalidade foi discutida em processo junto ao TCU. A questão controvertida está na interpretação do art. 167, VI, da CF, que veda "a transposição, o remanejamento ou a transferência de recursos de uma categoria de programação para outra ou de um órgão para o outro, sem prévia autorização legislativa". O autor assevera que o Manual Técnico de Orçamento considera a "Justiça do Trabalho" um órgão, e os Tribunais (TST e TRT), unidades orçamentárias desse órgão; no entanto, pondera que o art. 92 da CF especifica serem órgãos da Justiça do Trabalho o TST, os TRTs e os Juízes do Trabalho. Ao ter em vista que os Tribunais são dotados de autonomia administrativa, com competência privativa para atos relacionados à sua própria organização, e autonomia financeira, que lhes permite elaborar suas propostas orçamentárias, entende não haver hierarquia entre os Tribunais que compõem a Justiça do Trabalho nem supremacia do TST sobre os Tribunais Regionais, concluindo, assim, que o TST não tem poder de veto sobre as propostas orçamentárias dos TRTs. ${ }^{279}$ Nisso, o Poder Judiciário difere dos demais poderes, nos quais:

279 Transferência..., p. 68. 
[...] todas as unidades orçamentárias de um mesmo órgão estão sujeitas, em última instância, a uma mesma autoridade (Presidente da Câmara dos Deputados, do Senado Federal e do Tribunal de Contas da união, conforme o caso), e no Poder Executivo, onde, em cada órgão, todas as unidades orçamentárias estão vinculadas, quer direta, mediante subordinação hierárquica, quer indiretamente, por meio da supervisão ministerial (orientação, coordenação e controle), ao poder decisório do Ministro de Estado da respectiva Pasta.

Frisa ainda que a Lei de Responsabilidade Fiscal, no art. 20, $\S 2^{\circ}$, III, $a$, considera órgãos, para os efeitos da citada lei, no Poder Judiciário Federal, os Tribunais referidos no art. 92 da CF. ${ }^{280}$ Conclui, assim, que, sem autorização legislativa prévia, "a transferência de recursos orçamentários entre tribunais do trabalho não é compatível com o ordenamento jurídico vigente". ${ }^{281}$

O raciocínio é coerente com as disposições constitucionais e legais pertinentes, sendo válida a conclusão à qual chegou, que leva à inconstitucionalidade das transferências de recursos realizadas na forma mencionada, sem prévia autorização legislativa.

\subsection{Os precatórios judiciários}

O sistema de execução contra a Fazenda Pública, realizado por meio de precatórios, conforme previsto na legislação brasileira, apresenta algumas questões quanto à autonomia financeira do Poder Judiciário, razão pela qual se justifica a abordagem do tema.

A execução por quantia certa contra a Fazenda Pública está prevista no art. 730 do Código de Processo Civil, segundo o qual, uma vez citada a Fazenda Pública, não havendo a oposição de embargos, o juiz requisitará o pagamento do valor devido por intermédio do Presidente do Tribunal competente, fazendo-se o pagamento na ordem de apresentação do precatório.

$\mathrm{Na}$ definição de Regis de Oliveira, "precatório ou ofício precatório é a solicitação que o juiz de primeiro grau faz ao presidente do tribunal respectivo para que

\footnotetext{
${ }^{280}$ Para o art. 92 da CF são órgãos do Poder Judiciário: o STF, o STJ, os TRFs e Juízes Federais, os Tribunais e Juízes do Trabalho, os Tribunais e Juízes Eleitorais, os Tribunais e Juízes Militares e os Tribunais e Juízes dos Estados e do Distrito Federal e Territórios.
} 
este requisite a verba necessária para o pagamento de crédito de algum credor perante a União, o Estado, o Distrito Federal ou o Município, em face de decisão judicial". ${ }^{282}$

$\mathrm{O}$ art. 100 da CF estabelece que "os pagamentos devidos pela Fazenda Federal, Estadual ou Municipal, em virtude de sentença judiciária, far-se-ão exclusivamente na ordem cronológica de apresentação dos precatórios e à conta dos créditos respectivos". ${ }^{283}$

Dessa forma, estabeleceu-se um mecanismo destinado ao pagamento dos credores da Fazenda Pública por valores devidos em razão de sentenças proferidas pelo Poder Judiciário.

$\mathrm{O} \S 1^{\mathrm{o}}$ do referido art. 100 torna obrigatória a inclusão, nos orçamentos das entidades de direito público, de dotações destinadas ao pagamento dos débitos constantes dos precatórios judiciários que tenham sido apresentados até o dia $1^{\mathrm{o}}$ de julho. Para o cumprimento dessa norma, as dotações orçamentárias e os créditos abertos serão consignados diretamente ao Poder Judiciário. Cabe ao Presidente do Tribunal que proferir a decisão exequenda determinar o pagamento, conforme as possibilidades financeiras $\left(\S 2^{\circ}\right.$ do art. 100). O Presidente do Tribunal pode ainda autorizar o sequestro da quantia necessária à satisfação do débito na hipótese de preterimento do direito de preferência (CF, art. 100, § 2 , in fine; CPC, art. 731).

O mecanismo para cumprir as disposições constitucionais referidas anteriormente, na esfera federal, está regulado, para o exercício de 2005, na LDO da união, arts. 25 a 27. Compete ao Poder Judiciário, até 20.7.2004, encaminhar à Comissão Mista ${ }^{284}$, ao órgão central do Sistema de Planejamento e de Orçamento Federal $^{285} \mathrm{e}$ às entidades devedoras a relação dos débitos constantes dos precatórios judiciários que deverão ser incluídos na proposta orçamentária de 2005, na forma prevista no art. 25 da LDO para 2005. As dotações orçamentárias das autarquias e das

\footnotetext{
281 Transferência..., p. 70.

282 Manual..., p. 161.

${ }^{283}$ É semelhante à redação do art. 67 da Lei no 4.320/64: “Os pagamentos devidos pela Fazenda Pública, em virtude de sentença judiciária, far-se-ão na ordem de apresentação dos precatórios e à conta dos créditos respectivos, sendo proibida a designação de casos ou de pessoas nas dotações orçamentárias e nos créditos adicionais abertos para esse fim".

${ }^{284}$ Comissão Mista de Planos, Orçamentos Públicos e Fiscalização - CF, art. 166, § $1^{\circ}$.

${ }^{285}$ Secretaria de Orçamento Federal (SOF) do Ministério do Planejamento.
} 
fundações públicas destinadas ao pagamento dos débitos oriundos de sentenças judiciais deverão ser integralmente descentralizadas aos Tribunais que proferirem as referidas decisões, o que ocorrerá de forma automática, logo após a publicação da lei orçamentária. Caberá ao Tribunal providenciar eventual complementação da dotação, caso essa se mostre insuficiente, cientificando a entidade devedora. E as liberações dos recursos realizar-se-ão diretamente para o órgão setorial das unidades responsáveis pelo pagamento do débito, de acordo com as regras de liberação previstas para o Poder Judiciário. $^{286}$

Assim tem ocorrido o pagamento dos precatórios na forma exigida pelo disposto no art. 100 da $\mathrm{CF}$, que prevê a inclusão obrigatória das dotações para o pagamento dos referidos débitos nas entidades de direito público, consignando-as diretamente ao Poder Judiciário.

Dessa forma, estabelece-se mecanismo que assegura o pagamento integral dos precatórios, o que é de extrema relevância para a autonomia institucional do Poder Judiciário, uma vez que o cumprimento das decisões proferidas por esse Poder é fator essencial para a garantia da ordem jurídica e, consequentemente, do Estado Democrático de Direito, conforme prevê o art. $1^{\circ}$ da CF. Essas determinações constitucionais e legais preveem estrita observância ao que foi determinado pelo Poder Judiciário, que exerce o controle sobre a ordem dos precatórios e o mecanismo de quitação desses débitos, evitando, assim, a interferência de outros Poderes no cumprimento dessas ordens de pagamento.

Há tratamento diferenciado no que se refere ao pagamento, conforme a modalidade do precatório. A Constituição prevê a categoria das requisições de pequeno valor e dos créditos de natureza alimentícia. E os precatórios propriamente ditos podem também ter diferença no tratamento, conforme a época em que tenham sido expedidos, tendo em vista os vários parcelamentos autorizados pela Constituição e sucessivas emendas constitucionais. No entanto, esse assunto não será abordado, por fugir ao escopo do presente trabalho, em que se pretende enfocar apenas os aspectos deste tema que se relacionam à autonomia financeira do Poder Judiciário.

${ }^{286}$ LDO para 2005, art. 26. 
No aspecto orçamentário, os precatórios, na esfera federal, estão sendo incluídos em programa específico, cuja ação é da modalidade "operação especial", uma vez que configura despesa que não contribui para a manutenção, expansão ou aperfeiçoamento das ações de governo, não resultando um produto, nem gerando contraprestação direta em bens ou serviços. ${ }^{287}$ Conforme os programas e as ações padronizadas para a união na elaboração do orçamento para o exercício de 2005, os precatórios inserem-se no programa 0901 (Operações especiais - Cumprimento de sentenças judiciais). ${ }^{288} \mathrm{O}$ mesmo ocorreu no orçamento de 2004, verificando-se que estes programas vinculam-se ao órgão respectivo. Assim, o STF, o STJ e os TRFs têm, vinculada a cada um deles, visualizando-se pela classificação funcional e por programas, a rubrica "0901 Operações especiais: cumprimento de sentenças judiciais". 289

Cabe ressaltar que as despesas com pagamento de precatórios e requisições de pequeno valor não se incluem nos limites fixados nos termos do art. 99 da CF (LDO da união para 2005 , art. $17, \S 1^{\circ}$ ).

No que tange à autonomia financeira do Poder Judiciário, cumpre ainda destacar dois pontos relevantes. O primeiro refere-se à inclusão no orçamento dos valores destinados ao pagamento dos precatórios judiciários. $\mathrm{O}$ segundo, às medidas a serem adotadas no caso de não pagamento dos precatórios.

Quanto ao primeiro ponto, a norma de maior relevância é o já citado $\S 1^{\circ}$ do art. 100 da CF, segundo o qual:

É obrigatória a inclusão, no orçamento das entidades de direito público, de verba necessária ao pagamento de seus débitos oriundos de sentenças transitadas em julgado, constantes de precatórios judiciários, apresentados até $1^{\circ}$ de julho, fazendo-se o pagamento até o final do exercício seguinte, quando terão seus valores atualizados monetariamente.

A clareza da determinação constitucional torna evidente a caracterização de crime de responsabilidade do Presidente da República no caso de seu descumprimento,

\footnotetext{
${ }^{287}$ Veja-se item 4.3 .3 deste trabalho.

${ }^{288}$ Manual técnico de orçamento..., p. 30-7.

${ }^{289}$ Orçamento da União para 2004, v. III, p. 71 (STF) e 81 (STJ). O mesmo ocorre com os órgãos que não integram o Poder Judiciário, que também têm o programa.
} 
em face do que dispõem o art. 85, VI e VII, da $\mathrm{CF}^{290,291}$, e especialmente o art. 12, 4, da Lei $\mathrm{n}^{\circ} 1.079 / 50$, cuja dicção é a seguinte: "São crimes de responsabilidade contra as decisões judiciárias: [...] 4) impedir ou frustrar pagamento determinado por sentença judiciária”.

É evidente que a não inclusão ${ }^{292}$ dos valores necessários à quitação dos precatórios, na forma do art. 100 da $\mathrm{CF}$, na proposta orçamentária encaminhada ao Congresso Nacional, configura o fato típico previsto no art. 12, 4, da Lei $\mathrm{n}^{\mathrm{o}}$ 1.079/50, pois frustra o pagamento determinado por sentença judicial, uma vez que, não incluído no orçamento o valor para o pagamento dos precatórios, esses evidentemente não serão pagos. $^{293}$

Também permitem caracterização de ato de improbidade administrativa, nos termos do art. 11 , II, da Lei $\mathrm{n}^{\circ} 8.429 / 92$, sujeitando o administrador às penas previstas no art. 12, III, do referido diploma legal. Prevê o dispositivo citado:

Art. 11. Constitui ato de improbidade administrativa que atenta contra os princípios da administração pública qualquer ação ou omissão que viole os deveres de honestidade, imparcialidade, legalidade e lealdade às instituições, e notadamente: $[\ldots]$

II - retardar ou deixar de praticar, indevidamente, ato de ofício.

Uma vez sendo obrigatória a inclusão no orçamento das dotações para o pagamento dos precatórios, a não realização desse ato evidencia omissão que viola deveres legais, configurando a hipótese ora descrita.

Não é possível ao Poder Legislativo, na apreciação da proposta de orçamento encaminhada pelo chefe do Poder Executivo, alterá-la, no sentido de reduzir, anular, ou,

\footnotetext{
290 “Art. 85. São crimes de responsabilidade os atos do Presidente da República que atentem contra a Constituição Federal e, especialmente, contra: [...] VI - a lei orçamentária; VII - o cumprimento das leis e das decisões judiciais."

${ }^{291}$ Neste sentido, manifesta-se Regis de Oliveira: “A Lei de Responsabilidade Fiscal não instituiu um tipo penal a identificar a infração pelo não pagamento do precatório alimentar. Logo, não há crime comum. Subsiste, no entanto, o crime de responsabilidade, nos exatos termos do art. 85, VI, da Constituição da República" (Precatório: análise..., p. 131).

292 Por parte do Presidente da República, no caso do orçamento federal.

${ }^{293}$ Essas regras aplicam-se também aos Governadores dos Estados, em face do disposto no art. 74 da Lei $n^{\circ} 1.079 / 50$. Em sentido semelhante está o art. $1^{\circ}$, XIV, do Decreto-Lei $n^{\circ}$ 201/67, que dispõe sobre a
} 
de qualquer outra forma, adotar medida tendente a frustrar o pagamento dos precatórios. Tal medida contraria frontalmente o disposto no art. 100 da CF, sendo, portanto, inconstitucional, eivando desse vício a lei orçamentária eventualmente aprovada nessas circunstâncias.

Uma vez incluídos no orçamento os valores destinados ao pagamento dos precatórios judiciários, cumpre destacar que a Lei de Responsabilidade Fiscal, em seu art. $9^{\circ}, \S 2^{\circ}$, veda a limitação de empenho das despesas "que constituam obrigações constitucionais e legais do ente, inclusive aquelas destinadas ao pagamento do serviço da dívida, e as ressalvadas pela lei de diretrizes orçamentárias”. A LDO da união para o exercício de 2005 contém o Anexo v, que enumera as "despesas que não serão objeto de limitação de empenho, nos termos do art. $9^{\circ}, \S 2^{\circ}$, da Lei Complementar 101, de 4 de maio de 2000". O item "I" elenca as "despesas que constituem obrigações constitucionais ou legais da união", especificando, no item 32, "sentenças judiciais transitadas em julgado, inclusive as consideradas de pequeno valor".

Em face das disposições constitucionais e legais vigentes, constata-se que, no exercício financeiro de 2005, todos os valores dos precatórios judiciários apresentados até $1^{\circ} .7 .2004$ deverão ser incluídos no orçamento a ser executado em 2005, sem a possibilidade de se contingenciarem os referidos valores, o que torna obrigatório o seu pagamento até o final do exercício.

Sendo a lei de diretrizes orçamentárias anual, tal dispositivo pode não constar expressamente em outra edição da lei. No entanto, é forçoso concluir que, ainda que não exista essa expressa menção na lei de diretrizes orçamentárias, como vem sendo feito, o contingenciamento dos valores destinados aos precatórios é inadmissível, ante a previsão contida no art. 100 da CF, cuja interpretação permite concluir nesse sentido. $\mathrm{O}$ artigo diz ser obrigatória a inclusão no orçamento dos valores destinados ao pagamento dos precatórios. Reduzida eficácia teria esse comando normativo se, após incluído no orçamento, fosse possível o contingenciamento dessas despesas, pois tal ato frustraria o cumprimento de decisões judiciais, o que caracteriza, inclusive, crime de responsabilidade, como já mencionado. E o pagamento dos precatórios, diante das 
razões já apontadas, configura obrigação constitucional e legal do ente, caso em que o contingenciamento é vedado, nos termos do art. $9, \S 2^{\circ}$, da Lei de Responsabilidade Fiscal, independentemente de ressalva expressa na lei de diretrizes orçamentárias.

Há de se fazer algumas considerações sobre as possíveis medidas a serem tomadas em caso de não pagamento dos precatórios, como anunciado anteriormente.

O pagamento dos precatórios representa importante aspecto da independência do Poder Judiciário, uma vez que dele depende parcela significativa da eficácia das decisões proferidas. A ineficácia decorrente do não cumprimento do que for por ele determinado macula de forma significativa a independência desse Poder.

Isso justifica atribuir-se ao Poder Judiciário o controle das dotações destinadas ao pagamento dos precatórios judiciários, na forma estabelecida pelo art. $100, \S 2^{\circ}$, da $\mathrm{CF}$, e vincula a independência efetiva desse Poder, da qual o pagamento dos precatórios representa parcela importante, à autonomia financeira, decorrente do controle que exerce sobre referidos valores.

Vários são os mecanismos previstos no ordenamento jurídico que visam dar cumprimento fiel a essas determinações judiciais que resultam nos precatórios. Já se fez referência à tipificação de crime de responsabilidade para a hipótese, bem como à caracterização de ato de improbidade administrativa, mas há ainda outros a destacar, como o caso do sequestro de recursos determinado pelo Presidente do Tribunal e o da intervenção.

O art. 78 do Ato das Disposições Constitucionais Transitórias, com a redação que lhe foi dada pela EC 30/00, prevê a possibilidade de o Presidente do Tribunal competente determinar o sequestro de recursos financeiros da entidade executada para destiná-los ao pagamento de precatórios.

\section{Diz o texto:}

Art. 78. Ressalvados os créditos definidos em lei como de pequeno valor, os de natureza alimentícia, os de que trata o art. 33 deste Ato das Disposições Constitucionais Transitórias e suas complementações e os que já tiverem os seus respectivos recursos liberados ou depositados em juízo, os precatórios pendentes na data de promulgação desta Emenda e os que decorram de ações 
iniciais ajuizadas até 31 de dezembro de 1999 serão liquidados pelo seu valor real, em moeda corrente, acrescido de juros legais, em prestações anuais, iguais e sucessivas, no prazo máximo de dez anos, permitida a cessão de créditos. [...]

$\S 4^{\circ}$ - O Presidente do Tribunal competente deverá, vencido o prazo ou em caso de omissão no orçamento, ou preterição do direito de precedência, a requerimento do credor, requisitar ou determinar o sequestro de recursos financeiros da entidade executada, suficientes à satisfação da prestação.

Uma vez preenchidos os requisitos previstos no caput do art. 78, havendo requerimento do credor, cabe ao Presidente do Tribunal promover o sequestro dos recursos necessários para pagar o precatório. Deverá fazê-lo em quaisquer das hipóteses autorizadas pelo referido dispositivo constitucional, ou seja: se vencido o prazo previsto no caput do art. 78 sem que o pagamento tenha sido efetuado por completo; se o orçamento for omisso, não contendo a previsão de recursos suficientes para a quitação; e se houver preterição do direito de precedência.

Foram ampliadas, para os casos mencionados, as hipóteses que autorizam o sequestro, previstas no $\S 2^{\circ}$ do art. 100 da CF, em que se contemplava apenas o caso de preterimento do direito de precedência.

Outro mecanismo destinado a tornar eficaz o sistema de precatórios, ainda mais relevante, por abranger a maior parte dos casos, e configurar um ato de força, é a intervenção.

$\mathrm{Na}$ hipótese do não pagamento de precatórios, aplica-se o disposto no art. 34, VI, da CF, que prevê a possibilidade de a união intervir nos Estados e no Distrito Federal para prover a execução de ordem ou decisão judicial, e no art. 35, IV, que prevê a possibilidade de o Estado intervir em seus Municípios quando o Tribunal de Justiça der provimento a representação com as mesmas finalidades.

A intervenção não tem se mostrado um mecanismo eficiente para obter a satisfação dos créditos representados pelos precatórios judiciários, em virtude, fundamentalmente, de entendimento do STF no sentido de que esta medida não se aplica nas hipóteses de "exaustão financeira" (ou "exaustão orçamentária", ou ainda “impossibilidade material”), em que não se evidencia a intenção do governante de deliberadamente não pagar o precatório, justificando o ato pela impossibilidade de fazê- 
lo ante a escassez de recursos, que, se destinados ao pagamento dos precatórios, comprometeriam a continuidade dos serviços essenciais à população.

O Tribunal de Justiça de São Paulo tem reiteradamente rejeitado a tese da impossibilidade financeira como justificativa para o não pagamento dos precatórios. Nesse sentido são várias as decisões, cujos trechos vale destacar:

Por outro lado, não poderia ser aceita eventual alegação de dificuldade econômica a inviabilizar o cumprimento da decisão judicial. Como já salientou este Egrégio Plenário: "nada pode escusar a impontualidade, nem mesmo a ausência de recursos que, admissível como verdadeira, não possui, todavia, o condão de justificar inadimplência, antes até mesmo concorrendo para agravá-la, pois denotaria a imprevisão do administrador, que teve tempo mais que suficiente para alocar recurso com que executar espontaneamente a obrigação, no tempo, modo e forma devidos. O brocardo ad impossibilita nemo tenetur nunca pode ser alçado a uma justificativa ao inadimplemento de dívida pública. No momento mesmo em que se deliberou efetuar a desapropriação de bens, cumpria ao Município prover-se de meios financeiros para o pagamento da indenização, fora do que estar-se-ia no condenável risco do confisco iníquo". ${ }^{294}$

Até mesmo o depósito de valor desatualizado já foi objeto de decisão favorável à intervenção:

Cumpre que o pagamento do precatório seja feito de forma atualizada, sem apelar para a remessa do expropriado para um novo processo de liquidação destinado a apurar um novo quantum, que por sua vez dará lugar a um novo precatório em um processo praticamente de remissão ao infinito. Logo, depósito tardio e insatisfatório é violador de preceito constitucional, consequentemente ensejador de intervenção. ${ }^{295}$

Diferente é a posição que tem sido adotada no STF, que, em decisões reiteradas, acolhe a tese de que só cabe decretar a intervenção, medida extrema que subtrai a autonomia estatal, no caso de descumprimento voluntário e intencional da decisão judicial definitiva. O não pagamento de precatório em virtude da insuficiência de recursos financeiros que caracterize a situação de exaustão financeira - fenômeno econômico-financeiro vinculado à baixa arrecadação tributária - não legitima a medida. ${ }^{296}$ No mesmo sentido a, decisão na Intervenção Federal 1.207-4/SP:

\footnotetext{
${ }^{294}$ Representação Interventiva 12.918-0, rel. Des. Ney Almada, v. u., j. em 11.9.1991, RJIOB 1/15666. No mesmo sentido: Intervenção Estadual 22.472-0, São Paulo, rel. Des. Viseu Júnior, v. u., j. 15.3.1995. ${ }^{295}$ Intervenção Estadual 22.146-0, São Paulo, rel. Des. Renan Lotufo, j. 15.2.1995.

${ }^{296}$ STF-Pleno, Agravo Regimental na Intervenção Federal 506, rel. Min. Maurício Corrêa, j. em 5.5.2004.
} 
O decreto de intervenção federal, em razão do atraso no cumprimento de precatório judicial, por ser medida extrema, deve atender à máxima da proporcionalidade, somente sendo determinado quando demonstrada a atuação dolosa e deliberada do ente federativo com finalidade de não pagamento de suas obrigações. ${ }^{297}$

Esse entendimento da Egrégia Corte não se mostra o mais adequado ao ordenamento jurídico brasileiro. O voto do Ministro Marco Aurélio ${ }^{298}$, vencido na decisão mencionada anteriormente, espelha bem a incompatibilidade dessa decisão, e a transcrição de parte dele é válida para deixar claros os argumentos que dificultam aceitar outra posição:

O Judiciário não prolata sentenças simplesmente formais, sentenças que, sob o ângulo do conteúdo, mostram-se inúteis. É ele o responsável final pelo restabelecimento da paz social provisoriamente abalada, pela prevalência do arcabouço normativo constitucional, pelo equilíbrio nesse embate Estadocidadão, evitando que forças direcionadas de forma momentânea e isolada venham a prevalecer, em detrimento de interesses da coletividade. É certo que o Estado tudo pode: legisla, executa as leis e julga os conflitos de interesse decorrentes dessa execução. Que o faça com absoluta fidelidade a regras geradoras da boa convivência na vida social democrática. Ocorrido o desvio de conduta de um dos Poderes, cumpre afastá-lo, prevalecendo o sistema de freios, e aí surge, com importância maior, o papel do Judiciário, ao qual, no Estado de Direito, cabe a última palavra sobre o conflito. Não lhe é dado silenciar, contemporizar, o que, a mais não poder, discrepa das comezinhas noções da atuação estatal, respaldando atitude que, em relação a credores, implica tripudiar, resulta em menosprezo. A falta de celeridade nas decisões judiciais não pode servir ao respectivo descumprimento. Mas é esse o sentimento que predomina. Constantemente os veículos de comunicação retratam a rebeldia de dignitários relativamente a decisões judiciais. Afirmase, com absoluto desprezo à responsabilidade maior, que não se cumprirá esta ou aquela decisão, pouco importando, até mesmo, que seja originária do Supremo Tribunal Federal e se mostre coberta pela preclusão. Parte-se da óptica: recorram ao Judiciário e esperem. Será essa uma sentença final? No momento em que oitenta por cento das ações que chegam aos tribunais superiores envolvem o Estado, partir-se, quanto aos débitos deste, retratados em sentenças judiciais, em precatórios, em requisições, para a teoria do "homem da mala" ou do "trem pagador", sem os quais não cabe deferir intervenção, é aceitar que o tempo e a ordem jurídica consagrem a atitude dos inadimplentes e protejam não só o Estado devedor, mas também o Estado contumaz no descumprimento de decisões judiciais, como se estas existissem para atender não aos anseios de justiça do próprio povo, mas a simples formalidade. Continuo acreditando que o exemplo a ser seguido, o bom exemplo, vem de cima; persevero na crença no Direito, no caráter perene dos princípios que o respaldam, na prevalência da Constituição como lei fundamental, nada justificando o abandono, o menoscabo de que vem sendo alvo. É hora de o Judiciário definir-se: ou bem zela pelo dever de guardião

${ }^{297}$ STF-Pleno IF 1.207-4/SP, j. 19.3.2003, redator para o acórdão Min. Gilmar Mendes. RT 817/159.

298 O Ministro Marco Aurélio reproduziu, em grande parte, o voto proferido na Intervenção Federal 2.953-8. 
máximo da ordem jurídica, ou se mostra sensível a atitudes que desta discrepam, e aí acaba como responsável pelo atual estado de coisas, que pode ser retratado em quadro estarrecedor quanto aos precatórios que vêm, nos diversos Estados, sendo liquidados, isso considerada a data de expedição.

E, em seguida, conclui:

\begin{abstract}
Da mesma forma, descabe agasalhar o elemento subjetivo, ou seja, a óptica segundo a qual não basta o simples descumprimento de decisão judicial para ter-se como aberta a via da intervenção, sendo necessário demonstrar a culpa ou o dolo na ausência da liquidação do precatório. Essa condição é estranha à ordem jurídica, mesmo porque não é crível que, havendo numerário para o pagamento, deixe a pessoa jurídica de direito público de implementá-lo. Prevalece o critério objetivo, o não cumprimento da ordem judicial, a inobservância do título executivo judicial, pouco importando saber a causa. Entendimento diverso implica, diante de definições políticas de gastos, ofensa ao primado do Judiciário, à certeza da valia dos julgamentos. $\mathrm{O}$ Estado vê-se sempre diante de dificuldades de caixa, sendo presumível, assim, a contumácia no descumprimento das obrigações pecuniárias estampadas em sentença. ${ }^{299}$
\end{abstract}

A posição do Ministro Marco Aurélio mostra ser mais compatível com a preservação da ordem jurídica, elemento essencial de um Estado Democrático de Direito.

Pode ocorrer, no entanto, a caracterização da absoluta e completa "exaustão financeira", à qual faz referência o STF em suas decisões. Ou seja, constata-se não existirem recursos suficientes para o pagamento dos precatórios.

Considerando a grande quantidade de receitas envolvidas no orçamento dos entes públicos, é muito difícil a caracterização desta situação, pois, no mais das vezes, sempre haverá recursos. O que ocorrerá é a necessidade de escolher-se em que aplicálos: se no pagamento de precatórios, se em outras despesas, muitas vezes obrigatórias por força de determinações constitucionais e legais, se em despesas que, ainda que não obrigatórias, mostrem-se imprescindíveis para a satisfação das necessidades básicas da sociedade. Mas, em tese, é possível ocorrer a absoluta e completa exaustão financeira: dado o acúmulo de precatórios não pagos ao longo de vários anos, não é desarrazoado admitir que, em determinado momento, o somatório deles ultrapasse o montante

${ }^{299}$ STF-Pleno - IF 1.207-4/SP - j. 19.3.2003, redator para o acórdão Min. Gilmar Mendes. RT 817/159, p. 167-8. Idêntica manifestação em: STF-Pleno. IF 2.772/SP, pres. e rel. Min. Marco Aurélio, rel. do acórdão Min. Gilmar Mendes, j. 8.5.2003, fls. 1440-1 dos autos. 
previsto para as receitas durante todo o exercício, tornando, de fato, impossível sua quitação.

A solução desta questão pode ser vislumbrada em parecer emitido pelo professor, jurista e hoje Ministro do Supremo Tribunal Federal Eros Grau, em 25.5.1992, na consulta formulada pelo então chefe da Assessoria Jurídica da Presidência da República, professor Gilmar Ferreira Mendes, hoje também Ministro do Supremo Tribunal Federal. ${ }^{300}$

O jurista identifica os princípios da legalidade da despesa pública e da sujeição da Administração às decisões do Poder Judiciário, sendo o primeiro um princípio de “direito posto" (está previsto expressamente no art. 37, caput, da CF) e o segundo um princípio de "direito pressuposto" (não expressamente enunciado, existe em estado de latência sob o ordenamento positivo). Mostra que os princípios caracterizam-se por possuírem uma dimensão que não é própria das regras jurídicas: a dimensão do peso ou importância. Ou seja, se houver conflito entre princípios, a solução dá-se com a avaliação do peso relativo de cada um deles. No caso de haver conflito entre o princípio da sujeição da Administração às decisões do Poder Judiciário (que agasalha o pagamento de precatórios) com o princípio da legalidade da despesa pública (na qual se inserem as despesas obrigatórias), há de se fazer a valoração dos princípios, com a finalidade de se decidir qual prevalece. Nesse caso, segundo o autor, deve ser privilegiado o princípio da sujeição da Administração às decisões do Poder Judiciário, que consubstancia um "princípio jurídico fundamental", verdadeiro "axioma de direito público". Portanto, devem ser pagos os precatórios. O problema agrava-se no caso da exaustão financeira, ou, como prefere o autor, exaustão orçamentária. A “exaustão orçamentária", em sua definição, "é a situação que se manifesta quando inexistirem recursos suficientes para que a Administração possa cumprir determinada ou determinadas decisões judiciais". ${ }^{301}$ Nesse caso, não se está diante de um conflito entre princípios, mas de um confronto entre decisões judiciais e a realidade, ou entre a realidade e o direito. Caracterizada essa situação - demonstrada e comprovada perante o STF, ressalta enfaticamente -, está-se diante de um "estado de necessidade", caso em

\footnotetext{
${ }^{300}$ Despesa Pública - princípio da legalidade - decisão judicial.

${ }^{301}$ GRAU, Despesa pública..., p. 102.
} 
que se justifica o não cumprimento das decisões judiciais. ${ }^{302}$ Do exposto no parecer, é possível concluir que, efetivamente, se não houver recursos suficientes - com a caracterização da chamada “exaustão orçamentária" -, não há como se exigir o pagamento de precatórios, por absoluta impossibilidade fática de fazê-lo.

Evidentemente, não há como acolher de maneira jurídica um pedido impossível de ser atendido. No entanto, a "exaustão orçamentária" deve estar inequivocamente demonstrada e comprovada junto ao STF. E, vamos mais além, deve ocorrer em hipóteses absolutamente excepcionais, nas quais não paire qualquer dúvida sobre a completa impossibilidade de haver recursos suficientes para o pagamento dos precatórios.

Resta a terceira hipótese, sobre a qual não houve referência expressa no parecer mencionado: o conflito entre a necessidade de pagar os precatórios e a de arcar com outras despesas imprescindíveis para a satisfação das necessidades básicas da sociedade. Os argumentos desenvolvidos no parecer podem ser utilizados para se concluir que, na hipótese, deve ser levado em consideração o que está em conflito com o princípio da sujeição da Administração às decisões do Poder Judiciário, caso em que será necessário saber quais exatamente são as despesas tidas como imprescindíveis. Se essas despesas permitirem que se caracterize, por exemplo, um conflito com o princípio do direito à saúde (CF, art. 196) - mediante demonstração inequívoca e comprovação cabal -, caberá ao intérprete ou aplicador do Direito valorar os dois princípios em conflito para atribuir maior peso a um deles e, assim, tomar a decisão, a qual, necessariamente, terá de ser específica para cada caso.

\subsection{A Lei de Responsabilidade Fiscal e os limites de despesas com pessoal do Poder}

\section{Judiciário}

Em 4 de maio de 2000, foi promulgada a Lei Complementar 101, que passou a ser denominada Lei de Responsabilidade Fiscal (LRF), elaborada com a finalidade de estabelecer normas de finanças públicas voltadas para a responsabilidade na gestão fiscal (art. $1^{\circ}$, caput, da LRF), visando, com isso, obter "uma drástica e veloz redução

${ }^{302302}$ Idem, p. 105-6. 
do déficit público e a estabilização do montante da dívida pública em relação ao Produto Interno bruto da Economia". ${ }^{303}$ Essa lei cumpre determinação dos arts. 163 e 169 da CF, que preveem a necessidade de lei complementar para dispor sobre finanças públicas e outros temas correlatos, como a limitação das despesas com pessoal. ${ }^{304}$

No art. $1^{\circ}, \S 1^{\circ}$, da LRF, vêm estabelecidas suas diretrizes:

\begin{abstract}
A responsabilidade na gestão fiscal pressupõe a ação planejada e transparente, em que se previnem riscos e corrigem desvios capazes de afetar o equilíbrio das contas públicas, mediante o cumprimento de metas de resultados entre receitas e despesas e a obediência a limites e condições no que tange a renúncia de receita, geração de despesas com pessoal, de seguridade social e outras, dívidas consolidada e mobiliária, operações de crédito, inclusive por antecipação de receita, concessão de garantia e inscrição em Restos a Pagar.
\end{abstract}

Essas diretrizes permitem reconhecer que a gestão fiscal responsável funda-se nos princípios do planejamento da ação governamental, da limitação dos gastos públicos e da transparência. Cabe destaque às normas que estabelecem limites para o administrador dos recursos públicos, especialmente no que se refere à contratação de operações de crédito e às despesas com pessoal. Outro pilar no qual se sustenta a gestão fiscal responsável é o princípio da transparência fiscal, que obriga o administrador a dar publicidade aos seus atos. Fundamentais também são as regras de controle e fiscalização das contas públicas, bem como as punições institucionais e pessoais para as transgressões à lei.

Entre as normas de maior relevância para a gestão fiscal responsável, sobressaem as relacionadas à limitação dos gastos, especialmente no que tange às despesas com pessoal.

O art. 19 fixa esses limites em 50\% da receita corrente líquida para a União, $60 \%$ da receita corrente líquida para os Estados, e 60\% para os Municípios. O art. 20 especifica os porcentuais, em cada unidade da Federação, para os respectivos Poderes Legislativo, Executivo e Judiciário. Os limites são os seguintes:

\footnotetext{
${ }^{303}$ Exposição de Motivos da LRF, abril de 1999, p. 1.

304 Já discorremos sobre o tema nos artigos "A Lei de Responsabilidade Fiscal. Principais aspectos" e "Lei de Responsabilidade Fiscal: aspectos jurídicos", razão pela qual boa parte dos argumentos aqui desenvolvidos reproduz ideias lançadas nesses textos anteriores.
} 
a) na esfera federal, $50 \%$ da receita corrente líquida, sendo 2,5\% para o Legislativo, incluído o Tribunal de Contas da união, 6\% para o Judiciário, 40,9\% para o Executivo, e 0,6\% para o Ministério Público da União;

b) $60 \%$ da receita corrente líquida, sendo 3\% para o Legislativo, incluído o Tribunal de Contas do Estado, 6\% para o Judiciário, 49\% para o Executivo e 2\% para o Ministério Público dos Estados;

c) na esfera municipal, $60 \%$ da receita corrente líquida, sendo $6 \%$ (seis por cento) para o Legislativo, incluído o Tribunal de Contas do Município, quando houver, e 54\% (cinquenta e quatro por cento) para o Executivo.

$\mathrm{O}$ art. 20 da LRF acabou afetando diretamente o Poder Judiciário, e de forma bastante importante, pois estabeleceu um limite para suas despesas com pessoal, que representam a parcela mais significativa de seus gastos totais, haja vista que os investimentos e outras despesas de custeio importam em porcentuais relativamente modestos se comparados com as despesas de pessoal.

A limitação do art. 20 trouxe grande polêmica quanto à sua constitucionalidade, tendo sido impetradas várias ações diretas de inconstitucionalidade junto ao STF atacando referido dispositivo $^{305}$, não sendo, no entanto, concedida medida liminar para suspender provisoriamente a sua eficácia. A ação continua em tramitação, não havendo decisão final.

A questão afeta a autonomia financeira do Poder Judiciário, o que torna necessária a abordagem do tema, pois reduz, na parte mais significativa de suas despesas, a liberdade de decidir sobre sua necessidade de gastos, impedindo, até mesmo, que o Poder Legislativo o faça, dada a impossibilidade de aumentar a disponibilidade de recursos caso sejam ultrapassados os limites fixados.

A limitação das despesas com pessoal do Poder Judiciário pela Lei de Responsabilidade Fiscal exige considerações que abrangem aspectos relacionados ao

\footnotetext{
${ }^{305}$ ADIn 2.238, impetrada pelos partidos políticos PC do b, PT e PSB; ADIn 2.241, impetrada pela Mesa da Assembleia Legislativa do Estado de Minas Gerais; ADIn 2.256, impetrada pela Associação dos Membros de Tribunais dos Contas do Brasil (ATRICON); ADIn 2.261, impetrada pela Associação Nacional dos Membros do Ministério Público (CONAMP) e ADIn 2.365, impetrada pelo Partido Comunista do Brasil (PC do B).
} 
federalismo e ao alcance das normas gerais de Direito Financeiro, que serão objeto de estudo a seguir.

\subsubsection{A Lei de Responsabilidade Fiscal e sua função como norma geral de Direito}

\section{Financeiro}

A Lei de Responsabilidade Fiscal, como mencionado, cumpre determinação do art. 163 da CF, o qual exige lei complementar para dispor sobre finanças públicas, dívida pública, concessão de garantias, emissão e resgate de títulos da dívida pública, fiscalização de instituições financeiras, câmbio e instituições oficiais de crédito. Assim, a LRF regula esses assuntos, bem como estabelece algumas normas de gestão financeira e patrimonial, nos termos do art. $165, \S 9^{\circ}$, II, além de fixar os limites das despesas com pessoal, como previsto no art. 169 , todos da CF.

A lei complementar é uma das espécies previstas em nosso processo legislativo, consoante dispõem os arts. 59, II, e 69, ambos da CF. As leis complementares têm por função complementar o texto da Constituição quando esta expressamente assim o determina, tornando eficazes normas que não são autoexecutáveis. Sua principal característica é o quorum qualificado, devendo ser aprovada por maioria absoluta. A lei complementar, muitas vezes, como na presente hipótese, tem a função de editar as chamadas normas gerais.

$\mathrm{O}$ art. 24 da CF prescreve o seguinte:

Art. 24. Compete à união, aos Estados e ao Distrito Federal legislar concorrentemente sobre:

I - direito tributário, financeiro, penitenciário, econômico e urbanístico;

II - orçamento; $[\ldots]$

$\S 1^{\circ}$ No âmbito da legislação concorrente, a competência da união limitar-seá a estabelecer normas gerais. [...]

$\S 3^{\circ}$ Inexistindo lei federal sobre normas gerais, os Estados exercerão a competência legislativa plena, para atender a suas peculiaridades. [...] 
O texto constitucional prevê ainda que, em matéria de Direito Financeiro e Tributário, haverá legislação concorrente, cabendo à União estabelecer, nesse campo, as normas gerais.

A existência e necessidade das referidas normas gerais devem-se à organização do Estado brasileiro, que tem a forma federativa, conforme previsto na $\mathrm{CF}$ (art. $1^{\circ}$ ).

A existência do Estado Federal pressupõe alguns requisitos que devem estar presentes no que tange aos entes que o compõem: a) descentralização política (que implica rígida repartição de competências); b) autonomia administrativa; c) autonomia legislativa (estabelecer as próprias leis); d) autonomia financeira; e) participação das entidades federadas na formação da vontade nacional.

Desses requisitos, cabe destaque, para este ponto da discussão, à autonomia legislativa, ou seja, tanto o governo central quanto os governos locais terão poderes para editar suas próprias leis.

Com isso, coexistirão, em um Estado Federal, várias categorias de leis: leis nacionais, leis federais, leis estaduais, leis municipais e uma série de outros tipos de diplomas normativos. Leis nacionais são aquelas destinadas a todos e a todo o território nacional (por exemplo: Código Penal, no caso brasileiro) e tratam de matéria que se aplica tanto à união quanto aos Estados, ao Distrito Federal e aos Municípios; já as leis federais, embora válidas em todo o território nacional, são aquelas que se destinam a atender aos interesses da união enquanto pessoa jurídica de direito público interno (por exemplo: Estatuto dos Funcionários Públicos Civis da união). Essa distinção tem relevância, na medida em que as normas gerais de Direito Financeiro configuram leis nacionais, não federais.

É necessário que essa coexistência de leis e de poderes para editá-las seja harmônica, haja vista ser o princípio federativo fundamental no caso brasileiro, constituindo-se, inclusive, em cláusula pétrea $\left(\mathrm{CF}\right.$, art. $\left.60, \S 4^{\mathrm{o}}, \mathrm{I}\right)$, inalterável por emenda constitucional.

Daí surgirem as normas gerais, como instrumentos úteis e, no mais das vezes, necessários, para dar coesão e harmonia a esse sistema jurídico do Estado Federal, pois 
terão de ser observadas por todas as esferas de governo, limitando a autonomia legislativa dos entes federados.

O alcance exato e função das normas gerais são questões bastante controvertidas, pois, se este alcance for diminuto, pouco ou nada resultará para sua finalidade, qual seja, estabelecer as diretrizes a serem cumpridas por todas as esferas de governo, conferindo maior coesão e harmonia ao ordenamento jurídico no Estado Federal; se o alcance for excessivo, pouco ou nada restará de autonomia legislativa para os entes que compõem a Federação.

Houve debate intenso entre juristas em razão de divergências ocorridas no campo do Direito Tributário a respeito deste tema, sendo interessante mencionar as principais teses.

Duas correntes formaram-se. uma, denominada corrente tricotômica, defende a tese de que a lei complementar, em matéria tributária, deve ter três funções: 1) dispor sobre conflitos de competência; 2) regular as limitações ao poder de tributar; e 3) estabelecer normas gerais em matéria tributária. A outra corrente, denominada impropriamente dicotômica, tem outra posição.

Geraldo Ataliba explicita os argumentos dessa corrente. Diz o eminente jurista que a edição de normas gerais é excepcional, devendo se restringir a princípios. Devem, pois, ser interpretadas restritivamente. ${ }^{306}$

Cabe às normas gerais apenas dispor sobre assuntos relacionados à manutenção da harmonia entre os entes da Federação, preservando o equilíbrio federativo, bem como sobre princípios, o que exclui a possibilidade de se fazer referência a detalhes que importariam em violar a autonomia legislativa dos entes federados.

Assim, as normas gerais de Direito Tributário devem regular tão somente os conflitos de competência e as limitações ao poder de tributar. Por haver dois temas a serem objeto de regulação, deu-se o nome de corrente dicotômica.

${ }^{306}$ Normas gerais de Direito Financeiro e Tributário e autonomia dos estados e municípios, p. 61. 
A denominação, no entanto, peca pela imprecisão, tendo em vista que a tese defende existir apenas uma função, qual seja: editar normas gerais de Direito Tributário. O conteúdo dessas normas gerais é que abrange as limitações ao poder de tributar e os conflitos de competência.

Portanto, para os seguidores da corrente dicotômica, as normas gerais passam a ter função bem mais reduzida, pois se restringem apenas, em matéria tributária, a fixar as limitações ao poder de tributar e a regular os conflitos de competência.

No entanto, vê-se nitidamente que o legislador constituinte optou pela corrente tricotômica, em face da redação do art. 146 da $C F \cdot{ }^{307} \mathrm{E}$, em outras áreas que não o Direito Tributário, muitas vezes não há essa especificação do conteúdo das normas gerais, como o faz o referido artigo.

Assim, independentemente da corrente à qual se filie, a questão fundamental permanece: tornar o conteúdo das normas gerais preciso. Trata-se de tarefa árdua, a respeito da qual não há consenso entre os estudiosos.

Rubens Gomes de Sousa destaca que as normas gerais devem ter a finalidade de manter uniformidade da legislação na Federação; assim, as normas que conceituam fato gerador devem somente preservar o sistema da discriminação de rendas, essencial à manutenção e à existência do regime federativo. ${ }^{308}$

O ex-governador Carlos Alberto de Carvalho Pinto, em monografia dedicada ao assunto, na tentativa de esclarecer o conteúdo das normas gerais, apresenta conclusão na qual explicita quais tipos de normas não seriam normas gerais. As conclusões são úteis para auxiliar na solução dos problemas, e vale mencioná-las.

\footnotetext{
307 “Art. 146. Cabe à lei complementar: I - dispor sobre conflitos de competência, em matéria tributária, entre a união, os Estados, o Distrito Federal e os Municípios; II - regular as limitações constitucionais ao poder de tributar; III - estabelecer normas gerais em matéria de legislação tributária, especialmente sobre: a) definição de tributos e de suas espécies, bem como, em relação aos impostos discriminados nesta Constituição, a dos respectivos fatos geradores, bases de cálculo e contribuintes; b) obrigação, lançamento, crédito, prescrição e decadência tributários; c) adequado tratamento tributário ao ato cooperativo praticado pelas sociedades cooperativas; d) definição de tratamento diferenciado e favorecido para as microempresas e para as empresas de pequeno porte, inclusive regimes especiais ou simplificados no caso do imposto previsto no art. 155, II, das contribuições previstas no art. 195, I e $\S \S 12$ e 13, e da contribuição a que se refere o art. 239."

${ }^{308}$ Normas gerais..., p. 27.
} 
O autor diz que:

a) não são normas gerais as que tenham por objeto uma ou outra pessoa de direito público;

b) não são normas gerais as que visem particularizadamente a terminadas situações ou institutos, com exclusão de outros da mesma espécie; e

c) não são normas gerais as que se afastem dos aspectos fundamentais básicos. ${ }^{309}$

Constata-se que essas considerações, se não dirimem por completo o problema, ao menos auxiliam o aplicador da lei a chegar a uma solução adequada em questões relacionadas à LRF, que é uma lei complementar destinada a estabelecer normas gerais de Direito Financeiro em matéria de finanças públicas.

Mostram-se de suma importância para o exame que se fará a seguir, quando o art. 20 da LRF será analisado tendo por contexto os argumentos ora expostos.

\subsubsection{O art. 20 da Lei de Responsabilidade Fiscal: a limitação de gastos com pessoal}

O art. 20 da LRF tem a seguinte redação:

Art. 20. A repartição dos limites globais do art. 19 não poderá exceder os seguintes percentuais:

I - na esfera federal:

a) 2,5\% (dois inteiros e cinco décimos por cento) para o Legislativo, incluído o Tribunal de Contas da união;

b) $6 \%$ (seis por cento) para o Judiciário;

c) 40,9\% (quarenta inteiros e nove décimos por cento) para o Executivo, destacando-se 3\% (três por cento) para as despesas com pessoal decorrentes do que dispõem os incisos XIII e XIV do art. 21 da Constituição e o art. 31 da Emenda Constitucional n ${ }^{\circ}$ 19, repartidos de forma proporcional à média das despesas relativas a cada um destes dispositivos, em percentual da receita corrente líquida, verificadas nos três exercícios financeiros imediatamente anteriores ao da publicação desta Lei Complementar;

${ }^{309}$ Normas gerais..., p. 41. 
d) $0,6 \%$ (seis décimos por cento) para o Ministério Público da União;

II - na esfera estadual:

a) 3\% (três por cento) para o Legislativo, incluído o Tribunal de Contas do Estado;

b) $6 \%$ (seis por cento) para o Judiciário;

c) $49 \%$ (quarenta e nove por cento) para o Executivo;

d) 2\% (dois por cento) para o Ministério Público dos Estados;

III - na esfera municipal:

a) $6 \%$ (seis por cento) para o Legislativo, incluído o Tribunal de Contas do Município, quando houver;

b) $54 \%$ (cinquenta e quatro por cento) para o Executivo.

$\S 1^{\circ}$ - Nos Poderes Legislativo e Judiciário de cada esfera, os limites serão repartidos entre seus órgãos de forma proporcional à média das despesas com pessoal, em percentual da receita corrente líquida, verificadas nos três exercícios financeiros imediatamente anteriores ao da publicação desta Lei Complementar.

$\S 2^{\circ}$ - Para efeito deste artigo entende-se como órgão:

I - o Ministério Público;

II - no Poder Legislativo:

a) Federal, as respectivas Casas e o Tribunal de Contas da união;

b) Estadual, a Assembleia Legislativa e os Tribunais de Contas;

c) do Distrito Federal, a Câmara Legislativa e o Tribunal de Contas do Distrito Federal;

d) Municipal, a Câmara de vereadores e o Tribunal de Contas do Município, quando houver;

III - no Poder Judiciário:

a) Federal, os tribunais referidos no art. 92 da Constituição;

b) Estadual, o Tribunal de Justiça e outros, quando houver.

$\S 3^{\circ}$ - Os limites para as despesas com pessoal do Poder Judiciário, a cargo da união por força do inciso XIII do art. 21 da Constituição, serão estabelecidos mediante aplicação da regra do $\S 1^{\circ}$.

$\S 4^{\circ}$ - Nos Estados em que houver Tribunal de Contas dos Municípios, os percentuais definidos nas alíneas $a$ e $c$ do inciso II do caput serão, respectivamente, acrescidos e reduzidos em $0,4 \%$ (quatro décimos por cento).

$\S 5^{\circ}$ - Para os fins previstos no art. 168 da Constituição, a entrega dos 
recursos financeiros correspondentes à despesa total com pessoal por Poder e órgão será a resultante da aplicação dos percentuais definidos neste artigo, ou aqueles fixados na lei de diretrizes orçamentárias.

$$
\S 6^{\circ}-(\text { vetado })^{310}
$$

O texto ora transcrito estabeleceu precisa e detalhadamente os porcentuais máximos da receita que cada uma das pessoas políticas (União, Estados, Distrito Federal e Municípios) pode gastar, especificando, inclusive, o porcentual a ser gasto, no máximo, pelos Poderes Legislativo, Judiciário e Executivo, além do Ministério Público e do Tribunal de Contas.

Considerando o exposto no item 7.5.1, é de se reconhecer a essa lei complementar - a Lei de Responsabilidade Fiscal - a função de estabelecer tão somente normas gerais.

O conteúdo das normas gerais, como visto, não pode incluir detalhes, devendo limitar-se a princípios e a normas voltados à uniformidade da legislação na Federação, bem como a prevenir e a dirimir conflitos de competência.

Assim, evidencia-se que a fixação de limites máximos a serem gastos no pagamento de despesas com pessoal, na esfera interna dos entes federados, extrapola os limites do que pode ser considerado norma geral.

Vai além, inclusive, do que autoriza a Constituição, consoante se pode depreender da leitura do art. 169, caput: "A despesa com pessoal ativo e inativo da união, dos Estados, do Distrito Federal e dos Municípios não poderá exceder os limites estabelecidos em lei complementar".

A determinação foi cumprida com o art. 19 da LRF, que fixou referidos limites em $50 \%$ para a união, $60 \%$ para Estados e $60 \%$ para os Municípios. O legislador

\footnotetext{
${ }^{310} \mathrm{O}$ dispositivo vetado tem a seguinte redação: "Somente será aplicada a repartição dos limites estabelecidos no caput, caso a lei de diretrizes orçamentárias não disponha de forma diferente". É a seguinte a justificativa do veto: "A possibilidade de que os limites de despesas de pessoal dos Poderes e órgãos possam ser alterados na lei de diretrizes orçamentárias poderá resultar em demandas ou incentivo, especialmente no âmbito dos Estados e Municípios, para que os gastos com pessoal e encargos sociais de determinado Poder ou órgão sejam ampliados em detrimento de outros, visto que o limite global do ente da Federação é fixado em Lei Complementar. Desse modo, afigura-se prejudicado o objetivo da lei complementar em estabelecer limites efetivos de gastos de pessoal aos três Poderes. Nessa linha de entendimen-
} 
excedeu-se ao incluir a especificação dos porcentuais na esfera dos Estados e dos Municípios, entes da Federação dotados de autonomia, conforme reza o art. 18 da CF: “A organização político-administrativa da República Federativa do Brasil compreende a união, os Estados, o Distrito Federal e os Municípios, todos autônomos, nos termos desta Constituição" (grifo nosso).

Depreende-se do artigo, sendo os entes autônomos nos termos da Constituição, que somente esta poderá lhes impor limites, não sendo conformes à Constituição limites impostos à sua revelia, como se afigura nesta hipótese, em que o art. 19 estabeleceu os porcentuais máximos de despesas com pessoal e o art. 20, indo além, imiscuiu-se na esfera de atuação de Estados e Municípios.

O respeito à autonomia dos entes da Federação exige que possam decidir sobre questões de seu interesse, como é o caso dos valores máximos de que podem dispor com seus Poderes Legislativo, Judiciário e Executivo.

Cabe lembrar que, no projeto de lei, a redação do art. 20 previa, em seu $\S 6^{\circ}$, de modo claro, a possibilidade de serem fixados limites diferentes, estabelecidos na lei de diretrizes orçamentárias, o que tornaria os porcentuais do art. 20 meramente indicativos. Nesse caso, respeitar-se-iam as autonomias dos entes federados. No entanto, houve veto, cujas razões já foram reproduzidas, tendo sido a lei publicada sem o referido $\S 6^{\circ}$, o que tornou os porcentuais nela fixados obrigatórios. ${ }^{311,312}$

\footnotetext{
to, o dispositivo contraria o interesse público, motivo pelo qual sugere-se a oposição de veto".

311 "Foi lamentável a oposição de veto a esse dispositivo. A Lei de Responsabilidade Fiscal coloca os entes da Federação em verdadeira camisa-de-força, ferindo-lhes a autonomia para definir as suas metas e prioridades por intermédio da lei de diretrizes orçamentárias", assevera Maria Sylvia Di Pietro (In: MARTINS; NASCIMENTO. Comentários à Lei de Responsabilidade Fiscal, arts. 18 a 28, p. 151).

${ }^{312} \mathrm{O} \S 5^{\circ}$ manteve referência à lei de diretrizes orçamentárias: "Para os fins previstos no art. 168 da Constituição, a entrega dos recursos financeiros correspondentes à despesa total com pessoal por Poder e órgão será a resultante da aplicação dos percentuais definidos neste artigo, ou aqueles fixados na lei de diretrizes orçamentárias". Em razão disso, há quem defenda a possibilidade de estabelecer porcentual diverso, como Marcos Nóbrega (A Lei de Responsabilidade Fiscal e os limites de despesas de pessoal: a função da lei de diretrizes orçamentárias, p. 234) e Jair Santana (Limites de gastos com pessoal no Poder Judiciário: os 6\% são referenciais, p. 789). A interpretação histórica da lei, no entanto, em face da clareza dos motivos que levaram ao veto, não permite outra interpretação. A lei posta, neste caso, excluiu a possibilidade de fixar porcentual diverso, o que leva à sua inconstitucionalidade, como se conclui a seguir.
} 
Do exposto, é forçoso concluir ser inconstitucional o art. 20 da LRF (LC 101/00), quando dispõe sobre os limites máximos que Estados, Distrito Federal e Municípios podem gastar com pessoal, relativamente aos poderes que o integram. 